\title{
Fluorescent Molecular Rotors as Dyes to Characterize Polysorbate-Containing IgG Formulations
}

\author{
Andrea Hawe, ${ }^{1,2}$ Vasco Filipe, ${ }^{1}$ and Wim Jiskoot ${ }^{1}$
}

Received October 15, 2009; accepted November 24, 2009; published online December 30, 2009

Purpose. The aim was to evaluate fluorescent molecular rotors (DCVJ and CCVJ), which are mainly sensitive to viscosity, for the characterization of polysorbate-containing $\operatorname{IgG}$ formulations and compare them to the polarity-sensitive dyes ANS, Bis-ANS and Nile Red.

Methods. IgG formulations with polysorbate 20 or 80 were stressed below the aggregation temperature and analyzed by steady-state and time-resolved fluorescence and by HP-SEC with UV and fluorescent dye detection (Bis-ANS and CCVJ). Furthermore, commercial protein preparations of therapeutic proteins (Enbrel ${ }^{\circledR} 50 \mathrm{mg}$, Humira ${ }^{\circledR} 40 \mathrm{mg}$ and MabThera ${ }^{\circledR} 100 \mathrm{mg}$ ) were aggregated accordingly and analyzed with CCVJ fluorescence and HP-SEC.

Results. Contrarily to (Bis-)ANS and Nile Red, the molecular rotors DCVJ and CCVJ showed low background fluorescence in polysorbate-containing buffers. Time-resolved fluorescence experiments confirmed the steady-state fluorescence data. Both DCVJ and CCVJ showed enhanced fluorescence intensity for aggregated $\operatorname{IgG}$ formulations and were suitable for the characterization of polysorbatecontaining IgG formulations in steady-state fluorescence and HP-SEC with dye detection (CCVJ). CCVJ was capable of detecting thermally induced aggregation in the commercial polysorbate-containing products Enbrel ${ }^{\circledR} 50 \mathrm{mg}$, Humira ${ }^{\circledR} 40 \mathrm{mg}$ and MabThera ${ }^{\circledR} 100 \mathrm{mg}$.

Conclusion. Fluorescent molecular rotors are suitable probes to detect aggregation in polysorbatecontaining $\operatorname{IgG}$ formulations.

KEY WORDS: aggregation; fluorescence; fluorescent molecular rotors; monoclonal antibodies; size-exclusion chromatography.

\section{INTRODUCTION}

Surfactants like polysorbate 20 and 80 , also known as Tween ${ }^{\circledR} 20$ or 80 , are commonly used excipients in formulations of therapeutic proteins. The main function of the amphiphilic polysorbates is to prevent protein adsorption at liquid-liquid, liquid-solid or liquid-air interfaces, which can lead to surface-induced denaturation and aggregation (1). A protective effect of polysorbates on protein stability has been shown during freeze-thawing (2), freeze-drying (3), mechanical stress (e.g. agitation, shaking or stirring $(2,4,5)$ ), and reconstitution of dried protein preparations (6), as well as for formulations containing silicone oil droplets (5). However, polysorbates can also negatively affect stability, e.g. at quiescent conditions during long-term stability (7). Furthermore, polysorbates can undergo various degradation reac-

Electronic supplementary material The online version of this article (doi:10.1007/s11095-009-0020-2) contains supplementary material, which is available to authorized users.

\footnotetext{
${ }^{1}$ Division of Drug Delivery Technology, Leiden/Amsterdam Center for Drug Research, Leiden University, P.O. Box 9502, 2300 RA, Leiden, The Netherlands.

${ }^{2}$ To whom correspondence should be addressed. (e-mail: ahawe@ chem.leidenuniv.nl)
}

tions, which can lead to a loss of its stabilizing properties and chemical modifications of proteins, such as oxidation (8).

Almost $70 \%$ of the marketed monoclonal antibody formulations contain polysorbate 20 or polysorbate 80 as stabilizing excipients $(9,10)$. Within those commercial preparations, the polysorbate concentrations range between $0.001 \%$ $(\mathrm{w} / \mathrm{v})$ polysorbate 80 (Reopro $\AA)$ (11) and $0.16 \%$ (w/v) polysorbate 20 (Raptiva ${ }^{\circledR}$ ) (12), with most formulations containing about 0.005 to $0.02 \%$ polysorbate 20 or 80 . One difference between the polysorbates is the lower critical micelle concentration of polysorbate 80 (ca. $0.0017 \%(\mathrm{w} / \mathrm{v}))$ compared to polysorbate 20 (ca. $0.007 \%(\mathrm{w} / \mathrm{v}))(8)$.

Polarity-responsive extrinsic fluorescent dyes, like BisANS, ANS or Nile Red, can enable the sensitive detection of aggregated and structurally changed protein molecules (13), which can be particularly useful during formulation screening (14). Aggregates composed of structurally perturbed monomers are more prone to interact with those dyes, than aggregates composed of native-like monomers (15). The underlying aggregation mechanism and aggregate properties, like size, can play a role as well (16), as they are often related to changes in polarity. In previous papers, we demonstrated that fluorescent dyes, above all Bis-ANS, are highly sensitive to detect heat-induced aggregation in $\mathrm{IgG}$ formulations, both in steady-state fluorescence spectroscopy and as dye detection in size-exclusion chromatography (HP-SEC) $(15,17)$. 
From an analytical perspective, it needs to be considered that polysorbates will most likely interfere with this approach, as the fluorescent properties of dyes like (Bis-)ANS or Nile Red are highly sensitive to the polarity of the environment (13). Therefore, the use of these polarity-sensitive dyes can be rendered impractical in the presence of polysorbates, as dyesurfactant interactions will lead to high background fluorescence. In fact, the interaction of polarity-sensitive fluorescent dyes with surfactants is utilized to determine surfactant content and critical micelle concentration (18-21).

Unlike Bis-ANS, ANS and Nile Red, the fluorescent properties of fluorescent molecular rotors, such as DCVJ and CCVJ, are mainly sensitive to changes in the viscosity of the environment and less to polarity (22-24). Based on this, molecular rotors have been used for non-mechanical determination of fluid viscosity (25). Publications on applications of fluorescent molecular rotors in the field of protein aggregate characterization are rare compared to the polarity-sensitive dyes (Bis-)ANS and Nile Red, and are so far limited to polysorbate-free formulations $(15,16,23)$.

The aim of this study was to evaluate the ability of the fluorescent molecular rotors DCVJ and CCVJ to detect aggregation in polysorbate-containing $\mathrm{IgG}$ formulations, in comparison with the polarity-sensitive dyes ANS, Bis-ANS and Nile Red. We demonstrate that DCVJ and CCVJ are wellsuited to identify protein aggregates in thermally stressed polysorbate-containing $\mathrm{IgG}$ formulations by using steady-state fluorescence spectroscopy and HP-SEC with fluorescent dye detection. Furthermore, the suitability of CCVJ to detect aggregation in stressed commercial products with high protein concentrations and high polysorbate concentration is shown.

\section{MATERIALS AND METHODS}

\section{Materials}

A recombinant humanized monoclonal antibody of the $\mathrm{IgG}_{1}$ subclass (IgG) with a molecular weight of $149 \mathrm{kDa}$, an isoelectric region between 9 and 10 and an aggregation temperature (Tagg $=$ the onset of aggregation monitored by the optical density at $350 \mathrm{~nm}$ during a thermal scan) of about $81^{\circ} \mathrm{C}(17)$ was used for the study. The $\mathrm{IgG}$ was formulated at a concentration of $1.0 \mathrm{mg} / \mathrm{ml}$ in $100 \mathrm{mM}$ sodium phosphate buffer $\mathrm{pH} 7.2$ without or with different concentrations of polysorbate 20 and polysorbate 80 (Fluka, Sigma-Aldrich, Buchs Switzerland). The formulations were filtered using 0.22 $\mu \mathrm{m}$ PES low binding syringe driven filter units (Millex ${ }^{\mathrm{TM}} \mathrm{GP}$, Millipore, Ireland). Sucrose, mannitol, sodium citrate, sodium citrate dehydrate and citric acid monohydrate were from Fluka (Fluka, Sigma-Aldrich Steinheim, Germany), glycerol from Merck (Merck KGaA, Darmstadt, Germany), arginine hydrochloride from SAFC (SAFC, Sigma-Aldrich Steinheim, Germany), ethanol and methanol from Biosolve (Biosolve B. V., Valkenswaard, The Netherlands), $\mathrm{NaH}_{2} \mathrm{PO}_{4}$ dihydrate, $\mathrm{Na}_{2} \mathrm{HPO}_{4}$ dihydrate and $\mathrm{NaCl}$ were from Sigma (Sigma, Sigma-Aldrich Steinheim, Germany).

4,4'-Dianilino-1,1'-binaphthyl-5,5'-disulfonic acid dipotassium salt, Bis-ANS, 8-anilino-1-naphthalenesulfonic acid, ANS, 9-(2-carboxy-2-cyanovinyl)julolidine, CCVJ (Sigma, Sigma-Aldrich Steinheim, Germany), 9-(2,2-dicyanovinyl) julolidine, DCVJ and Nile Red (Fluka, Sigma-Aldrich, Buchs
Switzerland) were used. Stock solutions of the dyes were prepared in $99.9 \%$ ethanol (Biosolve B.V., Valkenswaard, The Netherlands). The dye content was determined by UV spectroscopy after dilution with deionized water (ANS, BisANS, and CCVJ), ethanol (DCVJ), or DMSO (Nile Red) to an absorbance between 0.1 and 1.0 at the absorption maximum of the respective dye.

Commercial products Humira ${ }^{\circledR} 40 \mathrm{mg}$ (Expiry date 052010, lot nr. 66781VA), Enbrel ${ }^{\circ} 50 \mathrm{mg}$ (Expiry date 03-2010, lot nr. 35561) and MabThera ${ }^{\circledR} 100 \mathrm{mg}$ (Expiry date 08-2011, lot nr. H0012) were obtained from local hospitals. Enbrel®50 mg contains $50 \mathrm{mg} / \mathrm{ml}$ etanercept and is polysorbate-free, MabThera ${ }^{\circledR} 100 \mathrm{mg}$ contains $10 \mathrm{mg} / \mathrm{ml}$ rituximab and $0.07 \%$ (w/v) polysorbate 80 and Humira ${ }^{\circledR} 40 \mathrm{mg}$ contains $50 \mathrm{mg} / \mathrm{ml}$ adalimumab and $0.1 \%(\mathrm{w} / \mathrm{v})$ polysorbate 80 .

\section{Stressing of IgG Formulations to Induce Aggregation}

Formulations with $1.0 \mathrm{mg} / \mathrm{ml} \mathrm{IgG}$ in $100 \mathrm{mM}$ phosphate, $\mathrm{pH} 7.2$ without polysorbate and with different concentrations of polysorbate 20 and 80 (see "Results" section) were prepared. To induce aggregation, $1.5 \mathrm{ml}$ of the formulation were stressed for 10 minutes at $75^{\circ} \mathrm{C}$ or $80^{\circ} \mathrm{C}$ in $1.5-\mathrm{ml}$ reaction tubes (Eppendorf, Hamburg, Germany) using a thermomixer (Eppendorf, Hamburg, Germany). Both temperatures were below the aggregation temperature of the $\mathrm{IgG}$, and no precipitation was observed after the thermal treatment.

\section{Stressing of Commercial Products to Induce Aggregation}

Enbrel@50 mg was stressed for $10 \mathrm{~min}$ at $70^{\circ} \mathrm{C}$, Humira ${ }^{\circledR} 40 \mathrm{mg}$ for $10 \mathrm{~min}$ at $60^{\circ} \mathrm{C}$ and $65^{\circ} \mathrm{C}$, and MabThera ${ }^{\circledR} 100 \mathrm{mg}$ for $10 \mathrm{~min}$ at $60^{\circ} \mathrm{C}, 65^{\circ} \mathrm{C}$ and $70^{\circ} \mathrm{C}$. For each condition, $800 \mu \mathrm{l}$ of the commercial product was filled in 1.5-ml reaction tubes (Eppendorf, Hamburg, Germany) and incubated at above-mentioned conditions using a thermomixer (Eppendorf, Hamburg, Germany). All formulations were optically clear after the thermal treatment, and no precipitation was observed. The formulations were allowed to cool down to room temperature and subsequently analyzed by HP-SEC and steady-state fluorescence spectroscopy using CCVJ.

The corresponding placebos contained $10 \mathrm{mg} / \mathrm{ml}$ sucrose, $5.8 \mathrm{mg} / \mathrm{ml} \mathrm{NaCl}, 5.3 \mathrm{mg} / \mathrm{ml}$ arginine $* \mathrm{HCl}$ and $3.9 \mathrm{mg} / \mathrm{ml}$ $\mathrm{Na}_{2} \mathrm{HPO}_{4} * 2 \mathrm{H}_{2} \mathrm{O}\left(\mathrm{pH}\right.$ 6.3) for Enbrel ${ }^{\circledR} 50 \mathrm{mg}$ (26), $6.2 \mathrm{mg} / \mathrm{ml}$ $\mathrm{NaCl}, 1.52 \mathrm{mg} / \mathrm{ml} \mathrm{Na} \mathrm{HPO}_{4} * 2 \mathrm{H}_{2} 0,0.3 \mathrm{mg} / \mathrm{ml}$ sodium citrate, $1.3 \mathrm{mg} / \mathrm{ml}$ citric acid monohydrate, $12.0 \mathrm{mg} / \mathrm{ml} \mathrm{mannitol} \mathrm{and}$ $1.0 \mathrm{mg} / \mathrm{ml}$ polysorbate $80(\mathrm{pH} 5.2)$ for Humira®40 mg (27) and $9 \mathrm{mg} / \mathrm{ml} \mathrm{NaCl}, 7.3 \mathrm{mg} / \mathrm{ml}$ sodium citrate dehydrate and $0.7 \mathrm{mg} / \mathrm{ml}$ polysorbate $80\left(\mathrm{pH}\right.$ 6.5) for MabThera ${ }^{\circledR} 100 \mathrm{mg}$ (28).

\section{UV Absorption Spectroscopy}

An Agilent 8453 UV-Vis spectrometer (Agilent, Waldbronn, Germany) was used to determine the $\mathrm{IgG}$ content in the formulations using an extinction coefficient of 1.49 for a $1.0 \mathrm{mg} / \mathrm{ml}$ solution for the absorption at $280 \mathrm{~nm}$. Samples of $1.0 \mathrm{ml}$ were measured in half-micro quartz cuvettes (Hellma, Kruibeke, Belgium) with a path length of $10 \mathrm{~mm}$. For IgG formulations, the UV absorbance was recorded from $240 \mathrm{~nm}$ to $360 \mathrm{~nm}$ using an integration time of $15 \mathrm{~s}$ and steps of $1 \mathrm{~nm}$. 
To determine the concentration of the dye stock solution, the following molar extinction coefficients were used: ANS $\left(4,900 \mathrm{M}^{-1} \mathrm{~cm}^{-1}\right.$ at $350 \mathrm{~nm}$ in water), Bis-ANS $\left(16,790 \mathrm{M}^{-1}\right.$ $\mathrm{cm}^{-1}$ at $385 \mathrm{~nm}$ in water) (29), Nile Red $\left(19,600 \mathrm{M}^{-1} \mathrm{~cm}^{-1}\right.$ at $552 \mathrm{~nm}$ in DMSO) (30), DCVJ $\left(65,900 \mathrm{M}^{-1} \mathrm{~cm}^{-1}\right.$ at $453 \mathrm{~nm}$ in ethanol) (23) and CCVJ $\left(25,404 \mathrm{M}^{-1} \mathrm{~cm}^{-1}\right.$ at $440 \mathrm{~nm}$ in water) (25). The spectra were recorded from 240 to $600 \mathrm{~nm}$ using an integration time of $5 \mathrm{~s}$ and steps of $1 \mathrm{~nm}$. All spectra were corrected for the absorbance of the particular solvent.

\section{Steady-State Fluorescence Spectroscopy}

A Tecan Infinite M1000 platereader (Tecan Benelux BVBA, Giessen, The Netherlands) was used to record the emission spectra of the extrinsic fluorescent dyes by top reading in black polypropylene 96-well plates (Greiner BioOne B.V., Alphen a/d Rijn, The Netherlands). $5 \mu$ l of a $100 \mu \mathrm{M}$ dye stock solution was added to $95 \mu \mathrm{l}$ protein solution to achieve a dye concentration of $5 \mu \mathrm{M}$, which is suitable for all the selected fluorescent dyes. $100 \mu \mathrm{l}$ of the $\mathrm{IgG} /$ dye mixture per well $(n=3)$ were measured within 30 min after dye addition. Preliminary studies had shown that there were no significant changes in fluorescence intensity and emission maximum for about $2 \mathrm{~h}$.

ANS was excited at $350 \mathrm{~nm}$ (emission scanned from: 370 to $650 \mathrm{~nm}$ ), Bis-ANS at $385 \mathrm{~nm}$ (emission: 400 to $650 \mathrm{~nm}$ ), CCVJ at $435 \mathrm{~nm}$ (emission: 450 to $650 \mathrm{~nm}$, DCVJ at $452 \mathrm{~nm}$ (emission: 470 to $650 \mathrm{~nm}$ ) and Nile Red at $550 \mathrm{~nm}$ (emission: 570 to $700 \mathrm{~nm}$ ). The fluorescence measurements were performed with slits of $5 \mathrm{~nm}$, steps of $2 \mathrm{~nm}$ and flashes of 4.8 Joule. Under these experimental settings, no inner filter effect and no disturbance by scattered excitation light was observed. By subtracting the background spectra of the respective dye-free controls from the emission spectra of the dye-containing samples, the contribution of light scattering at the solvent manifested as Raman peak was removed from the spectra.

\section{Time-Resolved Fluorescence}

Time-resolved fluorescence measurements were performed on a LifeSpec-ps fluorimeter (Edinburgh Instruments Ltd., Livingston, UK) with a PMT detector module. As excitation source, PDL 800-B picosecond pulsed diode lasers (Picoquant, Berling, Germany) operating at a frequency of $10 \mathrm{MHz}$ of $375 \mathrm{~nm}$ (Bis-ANS) and $450 \mathrm{~nm}$ (DCVJ) were used. On the emission side, a cut-on filter of $495 \mathrm{~nm}$ was used for both dyes. The temperature was kept constant at $25^{\circ} \mathrm{C}$. Samples $(900 \mu \mathrm{l})$ were measured in half-micro quartz fluorescence cuvettes (Hellma, Kruibeke, Belgium). The fluorescence decays were measured over $100 \mathrm{~ns}$ for Bis-ANS and $50 \mathrm{~ns}$ for DCVJ up to a peak count of 10,000 using 2,048 channels. The dynamic instrumental response function (IRF) was recorded by measuring the 'decay' of a diluted LUDOX ${ }^{\mathrm{TM}}$ LS colloidal silica solution in water. To deconvolute the IRF and to fit the intensity decay, the FAST software package (Edinburgh Instruments Ltd., Livingston, UK) was used. Calculations therein are based on a combination of global least square analysis minimization and non-negative singular value decomposition. Depending on the resulting decays, between 1 and 4 exponentials (i.e., discrete lifetimes) were required for a suitable fit of the data. The goodness of fit was evaluated by the reduced $\mathrm{Chi}^{2}$ criterion and the residuals of the fit. The average lifetime was calculated as:

$$
\text { average lifetime }=\sum_{n=1}^{n} \operatorname{tau}_{n} * \frac{f_{n}}{100} .
$$

where tau is a discrete lifetime component, $n$ is the number of lifetime components, and $f_{n}$ is the fractional contribution (in \%) of lifetime $n$.

\section{HP-SEC}

Size exclusion chromatography was performed using a TSKgel4000SWXL column (Tosoh Biosep, Stuttgart, Germany) on an isocratic HPLC system with a Waters 515 pump, a Waters 717 plus autosampler, a Waters 474 fluorescence detector (Waters, Milford Massachusetts, USA) and a Shimadzu SPD $\mathrm{UV} / \mathrm{Vis}$ detector (Shimadzu, Tokyo, Japan) at a flow rate of $0.5 \mathrm{ml} / \mathrm{min}$. For the standard $\mathrm{IgG}$ formulations of $1.0 \mathrm{mg} / \mathrm{ml} 50 \mu \mathrm{l}$ sample was injected. For the commercial products, $5 \mu \mathrm{l}$ were injected for Enbrel ${ }^{\circledR} 50 \mathrm{mg}$ and Humira ${ }^{\circledR} 40 \mathrm{mg}$ and $10 \mu \mathrm{l}$ for MabThera $₫ 100 \mathrm{mg}$.

The mobile phase was composed of $50 \mathrm{mM}$ sodium phosphate, $150 \mathrm{mM}$ arginine and $0.025 \% \mathrm{NaN}_{3}, \mathrm{pH} 7.0$. To quantify aggregation in the $\mathrm{IgG}$ formulations, UV absorption at $280 \mathrm{~nm}$ was used. For fluorescence dye detection $5 \mu \mathrm{M} \mathrm{CCVJ}$ or $2.5 \mu \mathrm{M}$ Bis-ANS were added to the mobile phase. CCVJ fluorescence was detected using excitation at $435 \mathrm{~nm}$ (bandwidth $18 \mathrm{~nm}$ ) and monitoring emission at $500 \mathrm{~nm}$ (bandwidth $18 \mathrm{~nm}$ ). For Bis-ANS excitation was at $385 \mathrm{~nm}$ (bandwidth $18 \mathrm{~nm}$ ) and emission at $485 \mathrm{~nm}$ (bandwidth $40 \mathrm{~nm}$ ).

\section{RESULTS AND DISCUSSION}

\section{Impact of Polarity and Viscosity on Dye Fluorescence}

In order to identify suitable dyes for the analysis of polysorbate-containing formulations, a number of dyes were compared for their sensitivity to polarity and viscosity. To do so, the fluorescence emission of the dyes was measured in $100 \mathrm{mM}$ phosphate $\mathrm{pH} 7.2$ (dielectric constant $\varepsilon=80.1$, viscosity at $\left.20^{\circ} \mathrm{C} \eta=1 \mathrm{mPa} \mathrm{s}\right), 10 \%(\mathrm{w} / \mathrm{v})$ sucrose $(\varepsilon=80.1$, $\eta=1.2 \mathrm{mPa} \mathrm{s})$, ethanol $(\varepsilon=25, \eta=1.2 \mathrm{mPa} \mathrm{s})$, methanol $(\varepsilon=$ $33.6, \eta=0.59 \mathrm{mPa} \mathrm{s})$ and glycerol $(\varepsilon=42.5, \eta=945 \mathrm{mPa} \mathrm{s})$ (Fig. 1). A considerable intensity increase combined with a blue shift of at most $32 \mathrm{~nm}$ was measured for Bis-ANS in ethanol and methanol. In glycerol, Bis-ANS fluorescence intensity did not increase as much, and the blue shift was only $10 \mathrm{~nm}$. DCVJ and CCVJ exhibited significantly higher fluorescence intensities in glycerol, but unchanged (CCVJ) or slightly increased (DCVJ) intensities in ethanol and methanol. The blue shift in organic solvents was higher than the one in glycerol.

The fluorescence of Bis-ANS (as well as similar dyes like ANS and Nile Red-results not shown) is mainly responsive to changes in polarity. This is evident from the inverse correlation of the intensity increase and blue shift of BisANS fluorescence with the dielectric constant, obvious for the aqueous solutions (dielectric constant $\varepsilon=80.1)$, glycerol $(\varepsilon=$ 


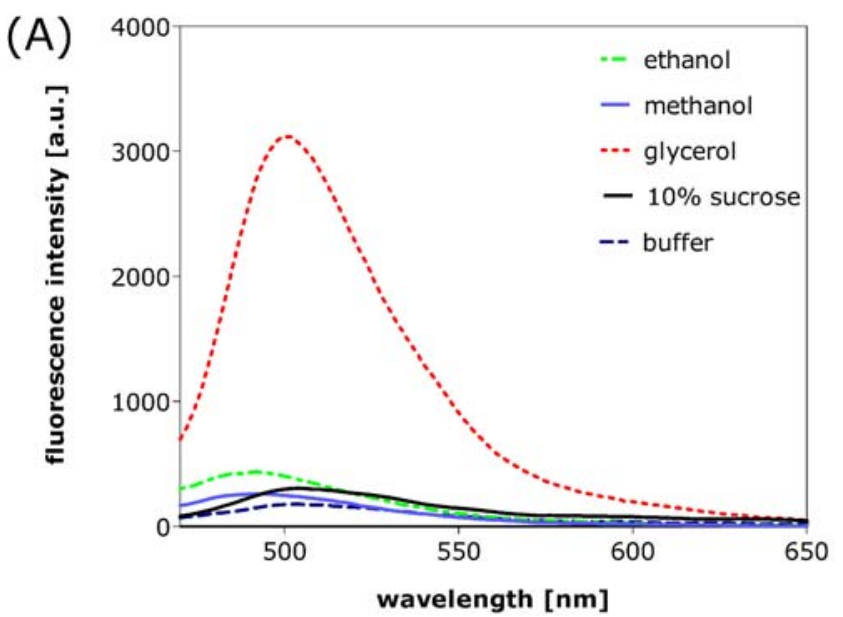

(B)

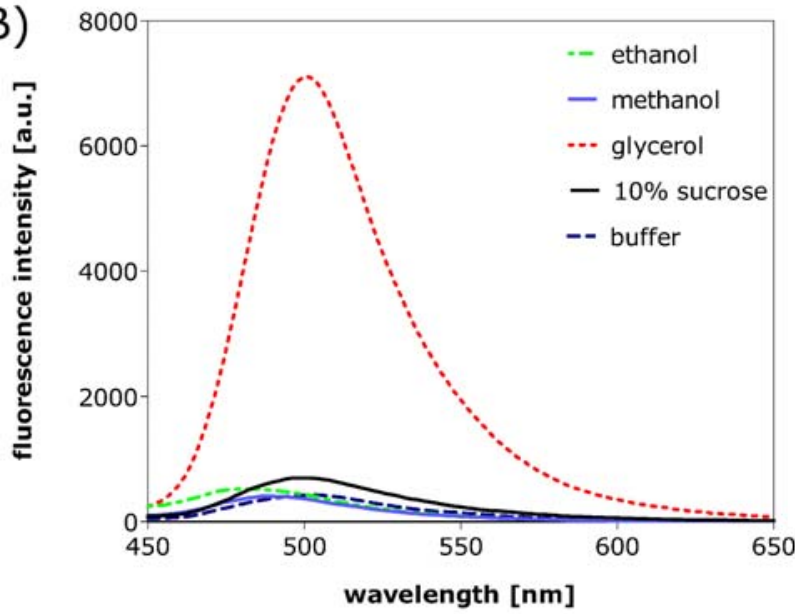

(C)

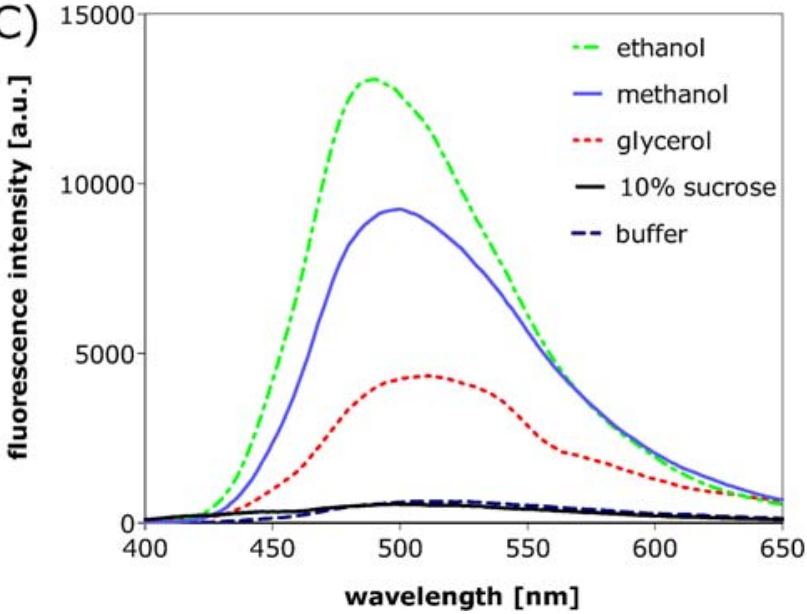

Fig. 1. Representative steady-state fluorescence spectra of $5 \mu \mathrm{M}$ DCVJ (A), $5 \mu \mathrm{M}$ CCVJ (B) and $5 \mu \mathrm{M}$ Bis-ANS (C) in $100 \mathrm{mM}$ phosphate $\mathrm{pH} 7.2$ (buffer), 10\% (w/v) sucrose, methanol, ethanol and glycerol.

42.5), methanol $(\varepsilon=33.6)$ and ethanol $(\varepsilon=25)$. This increase in quantum yield and blue shift of the emission maximum can be ascribed to the inhibition of the essentially non-fluorescent twisted intramolecular charge transfer (TICT) state in nonpolar environments $(13,31,32)$. Molecular rotors, like DCVJ and CCVJ are less sensitive to polarity with respect to changes in quantum yield; however, the position of the emission maximum remains sensitive to polarity, as obvious from the blue shift of DCVJ and CCVJ in methanol and ethanol (Fig. 1A,B).

Molecular rotors mainly experience an increase in quantum yield when present in highly viscous environments like glycerol $\left(\eta=945 \mathrm{mPa}\right.$ s at $20^{\circ} \mathrm{C}$, as compared to $1 \mathrm{mPa}$ s for water) (22-24), as described in detail by Haidekker et al., 2005 (22). This can be explained by a charge transfer excited singlet state, which rapidly decays in a non-radiative way through internal rotation around a donor acceptor bond (Fig. 2). When this internal rotation is hindered, e.g. due to an increase in viscosity or sterical constraints when the dye is bound to protein aggregates, the radiative decay of the excited state is favored, and an increase in quantum yield is obtained $(22,23)$.

One concern in using fluorescent molecular rotors for formulation screening might be an interference of excipients that affect the viscosity of the formulations. This is particularly relevant for sugars, like sucrose of trehalose, which are typically added in concentrations between 2 and $10 \%(\mathrm{w} / \mathrm{v})$ to the formulations, where, e.g., a viscosity of $1.17 \mathrm{cP}$ is found for $10 \%(\mathrm{w} / \mathrm{v})$ sucrose at $25^{\circ} \mathrm{C}(33)$. The fluorescence intensities of CCVJ and DCVJ were slightly increasing for a $10 \%(\mathrm{w} / \mathrm{v})$ sucrose solution (Fig. 1A,B), whereas Bis-ANS fluorescence was not affected by the addition of sucrose (Fig. 1C). However, no disturbance by sucrose is expected in the concentration range generally used within protein formulations, as the increase in fluorescence is minor compared to the increase expected for stressed protein material. Nonetheless, when using fluorescent dyes for formulation screening, it is of great importance to perform a background correction for the fluorescence of the particular placebo when comparing formulations with different types and amounts of excipients.

Essentially, the low sensitivity of their quantum yield to polarity changes makes DCVJ and CCVJ ideal candidates for the characterization of proteins in polysorbate-containing formulations. Therefore, in the following sections, we will focus on molecular rotors for the characterization of polysorbate-containing formulations and compare them to the polarity-sensitive dyes (Bis-)ANS and Nile Red. Steady-state and time-resolved fluorescence experiments were done for both polysorbate 20 and polysorbate 80 . To avoid redundancies, only the results obtained with polysorbate 20 -containing formulations will be shown, as the results obtained with polysorbate 80 were very similar.

\section{Steady-State Fluorescence of Dyes in IgG Formulations Spiked with Polysorbate 20}

A formulation with $1.0 \mathrm{mg} / \mathrm{ml} \mathrm{IgG}$ in $100 \mathrm{mM}$ phosphate $\mathrm{pH} 7.2$ (non-stressed, NS, and stressed for $10 \mathrm{~min}$ at $80^{\circ} \mathrm{C}$,
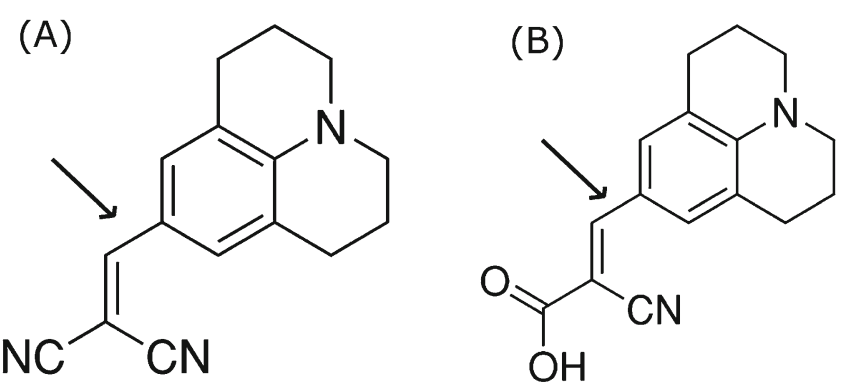

Fig. 2. Structure of molecular rotors DCVJ (A) and CCVJ (B). The arrow marks the bond where internal rotation in the excited state takes place. 
HT), as well as the corresponding formulation placebo, were spiked with polysorbate 20 to final concentrations between 0 and $0.1 \%(\mathrm{w} / \mathrm{v})$. Aggregates created by the thermal stress interact with non-covalent extrinsic dyes, resulting in an increase in fluorescence intensity, as described in detail in our previous publications $(15,17)$. The rationale behind spiking with polysorbate after the application of thermal stress was to obtain comparable levels and types of aggregates in the formulations but varying the polysorbate 20 concentration. Analysis of the spiked $\mathrm{IgG}$ preparations confirmed that the addition of polysorbate 20 did not alter the properties of the samples with respect to Z-average and polydispersity index in dynamic light scattering, as well as aggregate content and relative recovery in HP-SEC in the time frame of the experiment (data not shown).

The polysorbate 20-spiked samples were analyzed by steady-state fluorescence spectroscopy after the addition of $5 \mu \mathrm{M}$ DCVJ, CCVJ, Bis-ANS or Nile Red (Fig. 3). Comparable spectra with respect to emission maximum and intensity were obtained for the dyes when added to placebo and the corresponding non-stressed IgG preparation, pointing at negligible interactions of the dyes with non-stressed IgG. Heat-stressed placebos showed similar dye fluorescence as non-stressed placebos (results not shown).

With rising polysorbate 20 concentrations in placebo and non-stressed IgG, Bis-ANS and Nile Red fluorescence intensity (Fig. 3C,D) was increasing much steeper than DCVJ fluorescence (Fig. 3A), whereas a slight decline was monitored in CCVJ fluorescence intensity (Fig. 3B). The high fluorescence signal of Bis-ANS and Nile Red in the presence of polysorbate 20 impeded a feasible detection of changes in the heat-stressed IgG formulation, already at polysorbate 20 concentrations of 0.01 to $0.05 \%$, like typically used for protein formulations. DCVJ and CCVJ were capable of detecting heat-induced changes in formulations without and with polysorbate 20 , obvious by the notably higher fluorescence intensity for the stressed formulation as compared to the equivalent non-stressed $\mathrm{IgG}$ formulation (Fig. 3A,B).
(A)

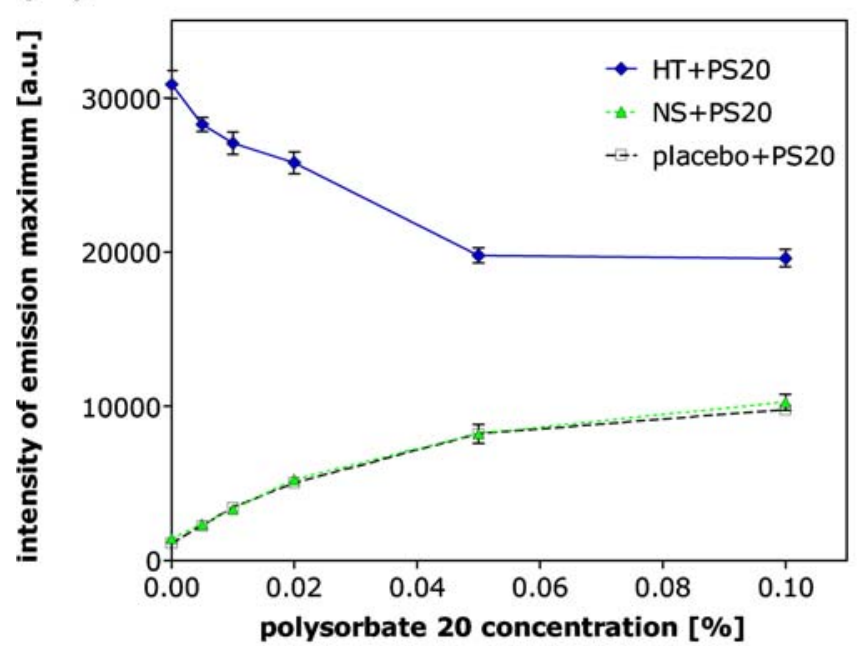

(C)

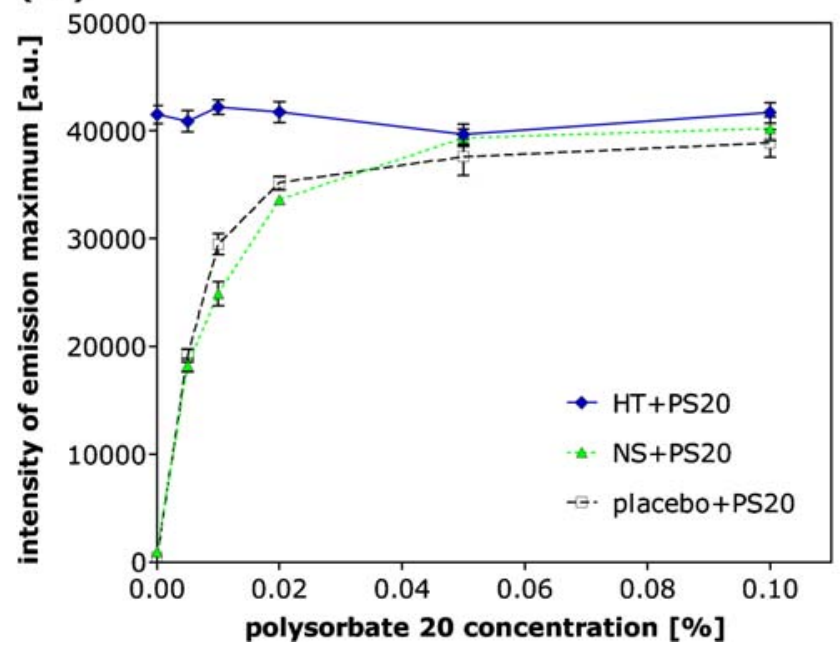

(B)

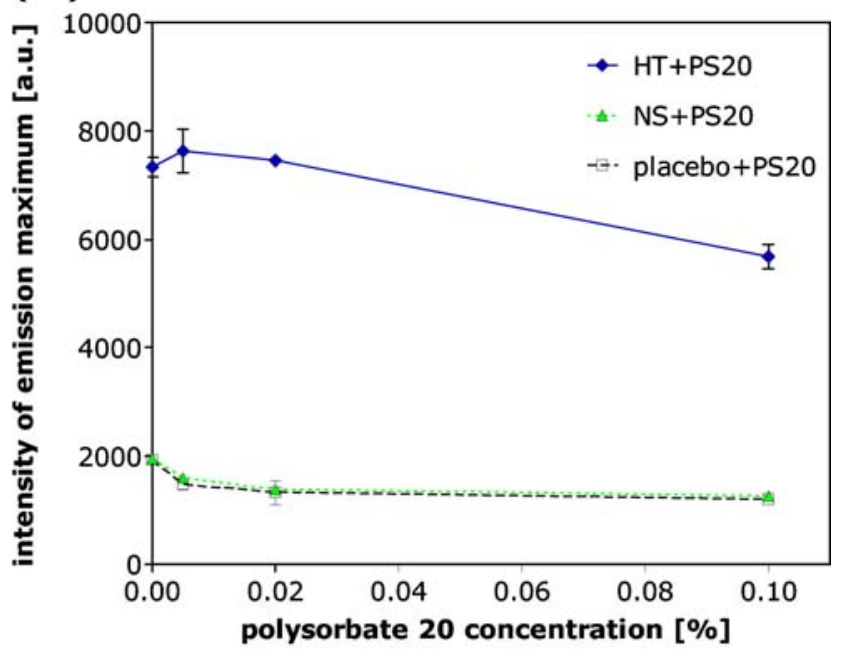

(D)

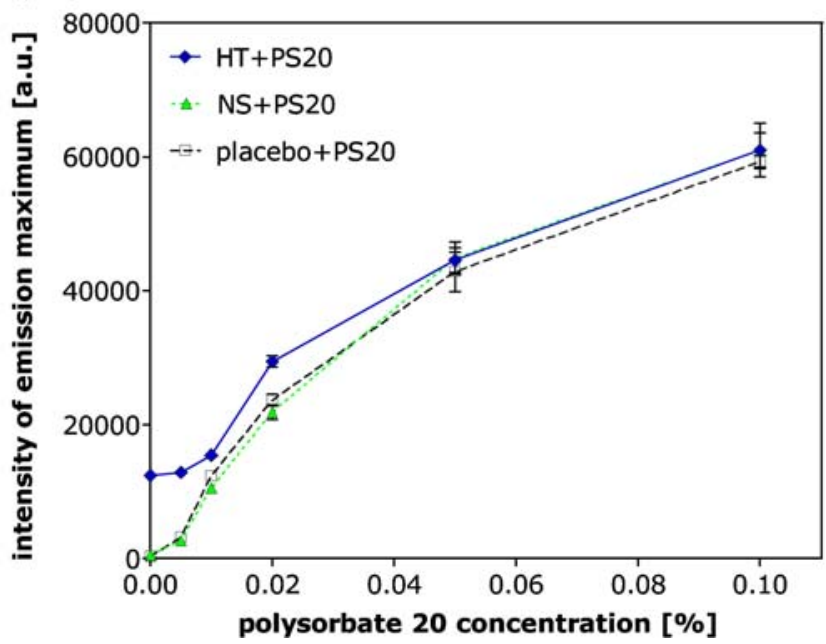

Fig. 3. Average maximum fluorescence intensity of $5 \mu \mathrm{M}$ DCVJ (A), $5 \mu \mathrm{M} \mathrm{CCVJ}$ (B), $5 \mu \mathrm{M}$ Bis-ANS (C) and $5 \mu \mathrm{M}$ Nile Red (D) for placebo, non-stressed IgG (NS) and $10 \mathrm{~min} 80^{\circ} \mathrm{C}$ heat-stressed IgG (HT) spiked with 0 to $0.1 \%$ polysorbate 20 (PS20). Error bars represent standard deviations of 3 independent experiments. 
Even at the highest tested polysorbate 20 concentration of $0.1 \%$, the fluorescence intensity for the heat-stressed formulations was clearly higher than for the corresponding placebo and non-stressed formulation.

Additionally, a decline of the fluorescence intensity for the heat-stressed formulations with increasing polysorbate 20 concentrations can be observed for CCVJ (Fig. 3B) and even more for DCVJ (Fig. 3A). For all dyes, a balance between free dye, dye interacting with stressed protein, and additionally for polysorbate-containing formulations dye interacting with polysorbate can be assumed:

$$
\text { free dye } \leftrightarrow \text { dye }- \text { stressed protien }
$$

$$
\text { dye }- \text { polysorbate } \leftrightarrow \text { free dye } \leftrightarrow \text { dye }- \text { stressed protein }
$$

For a polysorbate-free heat-stressed formulation (Eq. 2), the increase in fluorescence intensity of the dyes can be attributed to their interaction with structurally altered, aggregated protein. The interaction of the dyes with polysorbate 20 is obvious from the increased fluorescence intensity of Bis-ANS, DCVJ and Nile Red when higher polysorbate 20 concentrations are present in the placebo (Fig. 3A, C, D). For CCVJ (Fig. 3B) an intensity increase was only observed at even higher polysorbate concentrations of about $0.5 \%$ (data not shown), which is far above the CMC. When increasing the polysorbate concentration in heatstressed IgG formulations, it can be expected that overall less dye molecules will interact with stressed protein, because the polysorbate will progressively compete with the protein aggregates for interaction with the dye molecules (Eq. 3). In the case of Bis-ANS and Nile Red, the dye-polysorbate interaction results in high fluorescence (obvious from the dye added to placebo), and the overall signal remains therefore high. In the case of DCVJ and CCVJ, the dye-polysorbate interaction leads to a lower fluorescence as compared to dyestressed protein interaction, which can explain the overall decrease of the fluorescence intensity for the polysorbatecontaining heat-stressed IgG formulations.

\section{Time-Resolved Fluorescence Measurements}

To gain deeper insight into the underlying photo-physical behavior of the dyes upon interaction with protein and polysorbate, fluorescence lifetime measurements were performed for DCVJ and Bis-ANS. The average lifetimes are shown Table I, whereas the fluorescence decays, as well as detailed results and description of the data fitting are found in the "Supplementary Material." As shown in Table I, the average lifetimes of DCVJ were short, which is in agreement with the literature (16). Slightly shorter average lifetimes were found for the polysorbate 20-containing formulations, as compared to those without polysorbate, which confirms the observation of lower fluorescence intensity at higher polysorbate 20 concentrations in steady-state fluorescence (Fig. 3B).

The fluorescence decays of Bis-ANS were clearly more influenced by polysorbate 20. Longer average lifetimes of about $5.6 \mathrm{~ns}$ were determined for Bis-ANS added to polysorbate 20-containing placebo and non-stressed $\mathrm{IgG}$,
Table I. Average Lifetimes ( $\operatorname{tau}_{\mathrm{ave}}$ ) Derived from the Time-Resolved Fluorescence Decays for $5 \mu \mathrm{M}$ DCVJ (Exc. $450 \mathrm{~nm}, \mathrm{Em}>495 \mathrm{~nm}$ ) and

\begin{tabular}{|c|c|c|}
\hline Sample & $\operatorname{tau}_{\mathrm{ave}}$ for $\mathrm{DCVJ}^{a}[\mathrm{~ns}]$ & $\begin{array}{l}\operatorname{tau}_{\mathrm{ave}} \text { for } \\
\text { Bis-ANS }^{a}[\mathrm{~ns}]\end{array}$ \\
\hline Buffer, $0 \%$ PS & 0.19 & 0.46 \\
\hline NS, $0 \%$ PS & 0.24 & 1.49 \\
\hline $10 \min 80^{\circ} \mathrm{C}, 0 \% \mathrm{PS}$ & 1.23 & 8.38 \\
\hline Buffer, $0.02 \%$ PS & 0.15 & 5.59 \\
\hline NS, $0.02 \%$ PS & 0.16 & 5.56 \\
\hline $10 \min 80^{\circ} \mathrm{C}, 0.02 \% \mathrm{PS}$ & 0.99 & 6.49 \\
\hline
\end{tabular}
$5 \mu \mathrm{M}$ Bis-ANS (Exc. $375 \mathrm{~nm}, \mathrm{Em}>495 \mathrm{~nm}$ )

${ }^{a}$ the standard deviations $(n=3)$ were less than $0.05 \mathrm{~ns}$ for DCVJ and less than $0.1 \mathrm{~ns}$ for Bis-ANS

compared to Bis-ANS added to polysorbate-free placebo $(0.49 \mathrm{~ns})$ or non-stressed $\mathrm{IgG}(1.49 \mathrm{~ns})$. For the interaction of Bis-ANS with polysorbate, a characteristic lifetime of about $5.5 \mathrm{~ns}$ could be identified, which was also dominating the decays of the polysorbate 20-containing $\operatorname{IgG}$ formulations. For Bis-ANS interacting with heat-stressed IgG, two characteristic lifetimes, one at about $6 \mathrm{~ns}$ and a longer component $>10$ ns, were measured (see "Supplementary Material"). Whereas the lifetime of 6 ns found for heat-stressed polysorbate-containing IgG formulations can be attributed to a combination of Bis-ANS interacting with polysorbate and with stressed $\mathrm{IgG}$, the longer lifetime of $>10 \mathrm{~ns}$ is specifically related to the interaction of Bis-ANS with heat-stressed IgG.

Time-resolved fluorescence confirmed the results from steady-state fluorescence and was particular useful to distinguish between Bis-ANS interacting with polysorbate and with heat-stressed IgG.

\section{Detecting Aggregates in Polysorbate-Containing Formulations with DCVJ, CCVJ and Bis-ANS}

From the spiking experiments, it was obvious that DCVJ and CCVJ are capable of detecting aggregates in the presence of polysorbates. To be more in step with actual formulation work practice, we evaluated the advantage of DCVJ and CCVJ over polarity-sensitive dyes ANS, Bis-ANS and Nile Red for the characterization of formulations that contain polysorbate already during the stress testing. For this experiment, $1.0 \mathrm{mg} / \mathrm{ml} \mathrm{IgG}$ was formulated in $100 \mathrm{mM}$ phosphate $\mathrm{pH} 7.2$ without and with $0.02 \%$ polysorbate 20 or 80 and heat-stressed for $10 \mathrm{~min}$ at $75^{\circ} \mathrm{C}$ and $80^{\circ} \mathrm{C}$. Fig. 4 shows the fluorescence emission spectra for DCVJ, CCVJ and Bis-ANS added at a concentration of $5 \mu \mathrm{M}$ to IgG formulations without and with $0.02 \%$ polysorbate 20 . For the polysorbate-free formulations, an increase in fluorescence intensity combined with a blue shift of less than $20 \mathrm{~nm}$ was measured for DCVJ and CCVJ in heat-stressed formulations (Fig. 4A,C). BisANS appeared to be the most sensitive dye to detect heatinduced changes in polysorbate-free formulations, indicated by the stronger intensity increase ( 9.8 -fold versus 3.8 -fold for DCVJ and 1.3-fold for CCVJ, respectively) and blue shift of about $15 \mathrm{~nm}$ for the formulation stressed for 10 minutes at $75^{\circ}$ C (Fig. 4E), as compared to the molecular rotors (Fig. 4A,C). 
(A)

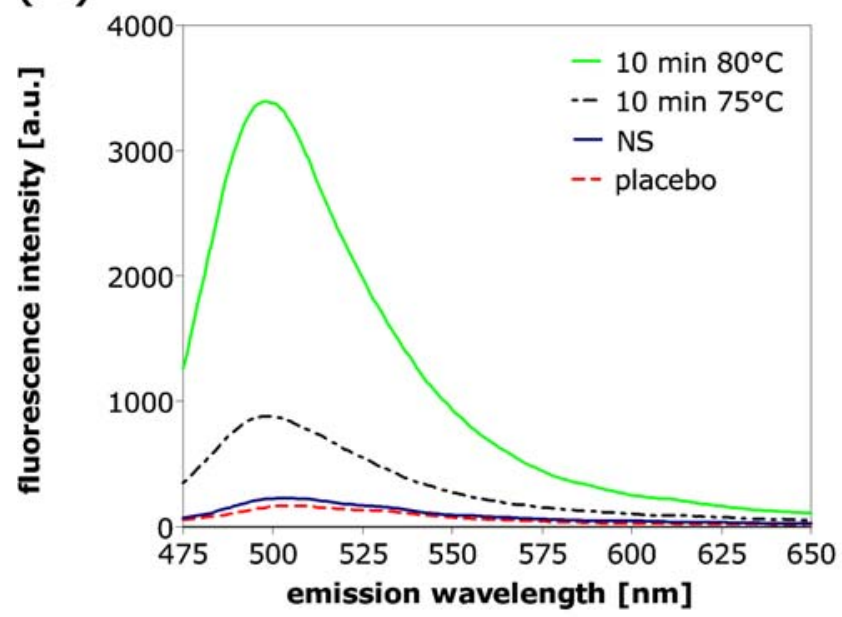

(C)

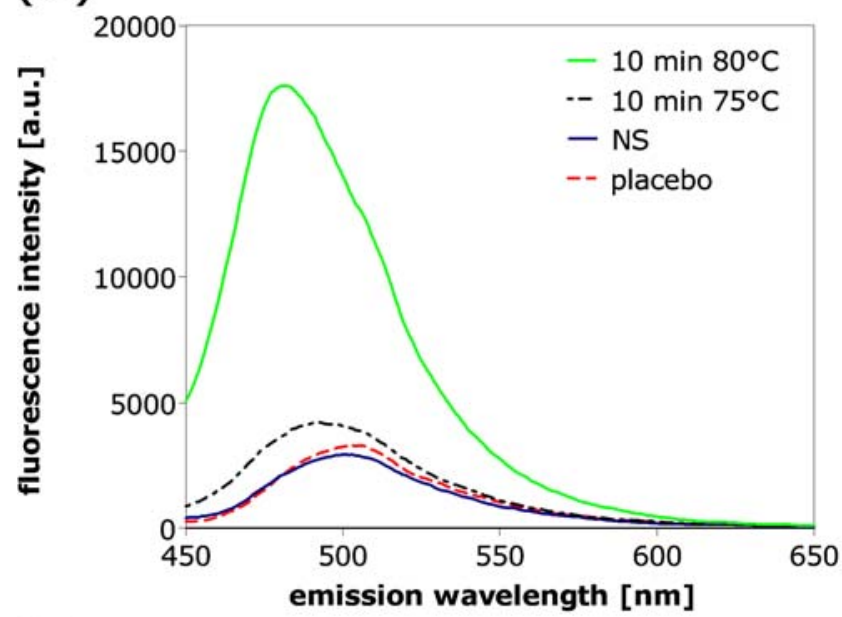

(E)

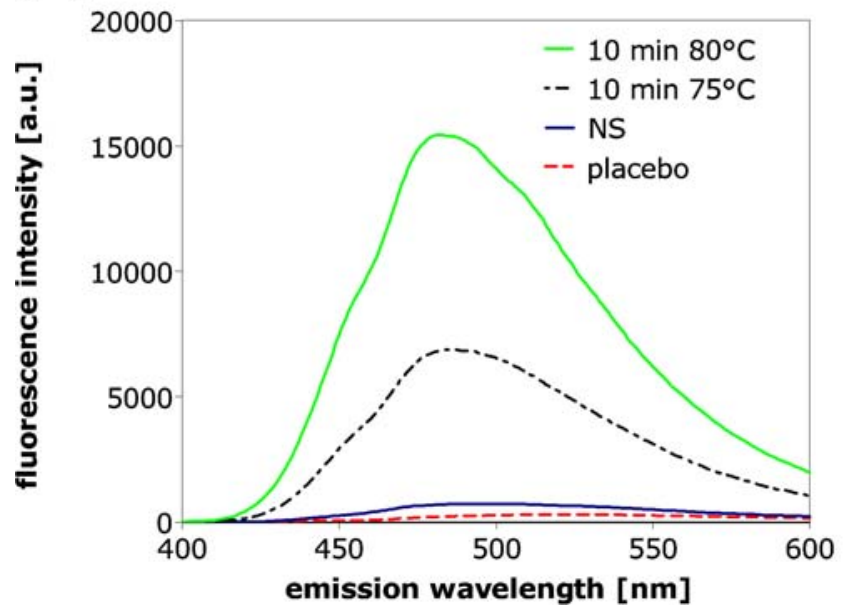

(B)

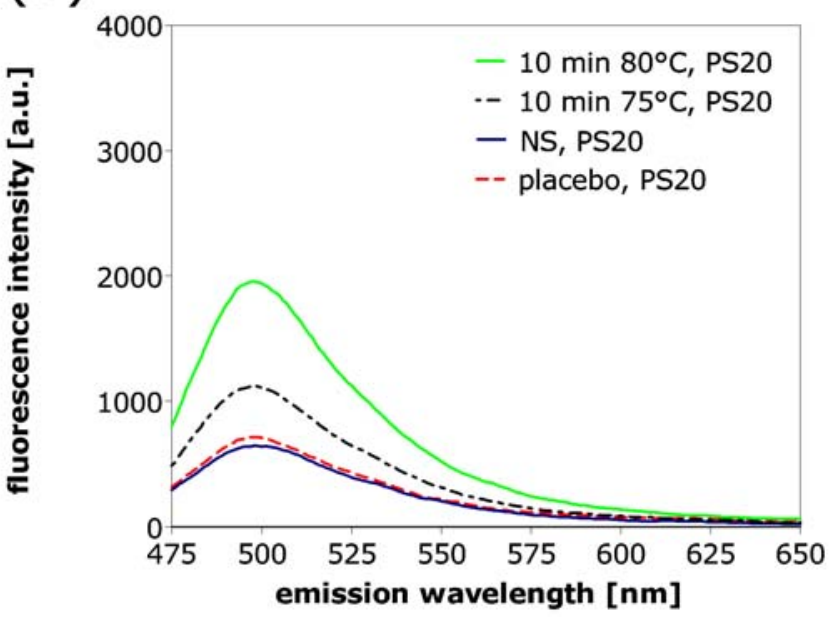

(D)

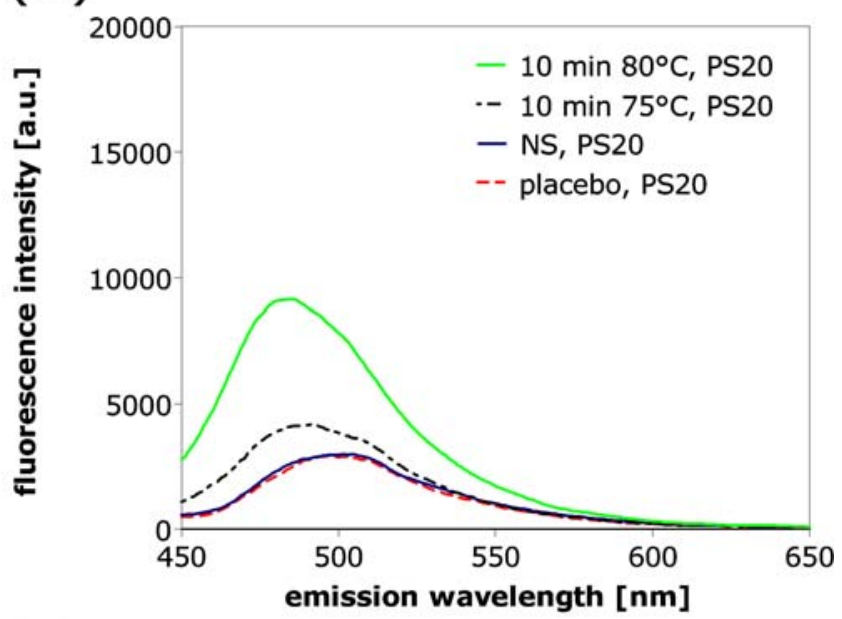

(F)

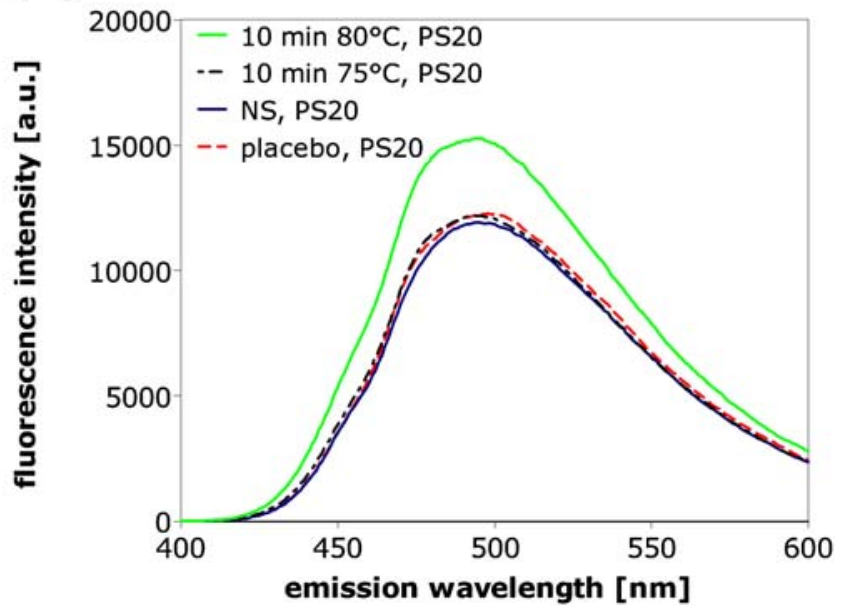

Fig. 4. Steady-state fluorescence spectra (average of $n=3$ ) of fluorescent dyes with placebo, non-stressed $\operatorname{IgG}$ (NS), IgG heat-stressed for $10 \mathrm{~min}$ at $75^{\circ} \mathrm{C}$ and $10 \mathrm{~min}$ at $80^{\circ} \mathrm{C}$ in the absence (A,C,E) and presence of $0.02 \%$ polysorbate 20 (PS20) (B,D,F). $5 \mu \mathrm{M}$ dye was used: DCVJ (A,B), $\mathrm{CCVJ}(\mathrm{C}, \mathrm{D})$ and Bis-ANS (E,F). The relative standard deviations of the maximum intensity were $<1 \%$ for placebo, $<3 \%$ for non-stressed IgG and $10 \mathrm{~min} 75^{\circ} \mathrm{C}$ stressed IgG and $<5 \%$ for $10 \mathrm{~min} 80^{\circ} \mathrm{C}$ stressed IgG. 
With DCVJ and CCVJ, it was possible to distinguish the polysorbate-containing formulations stressed for 10 minutes $75^{\circ} \mathrm{C}$ and $80^{\circ} \mathrm{C}$ from the non-stressed $\operatorname{IgG}$ and placebo control (Fig. 4B,D). Bis-ANS, on the other hand, was found to be less suitable for the characterization of polysorbatecontaining formulations, due to the high background fluorescence of the dye in polysorbate-containing placebo and unstressed IgG formulations, which partly (for the $80^{\circ} \mathrm{C}$ stressed sample) or completely (for the $75^{\circ} \mathrm{C}$ stressed formulation) impeded the detection of changes in the heatstressed formulations (Fig. 4B). The same accounts for ANS and Nile Red (data not shown).

\section{HP-SEC with Online CCVJ and Bis-ANS Fluorescence Detection}

Non-stressed, heat-stressed $\operatorname{IgG}\left(10 \mathrm{~min} 75^{\circ} \mathrm{C}\right.$ and $\left.80^{\circ} \mathrm{C}\right)$ and placebo without and with $0.02 \%$ polysorbate 20 or 80 were analyzed by HP-SEC using UV detection at $280 \mathrm{~nm}$ (Fig. 5) and fluorescent dye detection, using either $2.5 \mu \mathrm{M}$ BisANS (excitation $385 \mathrm{~nm}$, bandwidth $18 \mathrm{~nm}$, emission $490 \mathrm{~nm}$, bandwidth $40 \mathrm{~nm}$ ) or $5 \mu \mathrm{M} \mathrm{CCVJ}$ (excitation $435 \mathrm{~nm}$, emission $500 \mathrm{~nm}$, bandwidths $18 \mathrm{~nm}$ ) in the mobile phase (Fig. 6). From the molecular rotors, CCVJ was chosen because the solubility in water is better than the one of DCVJ, because one of the nitrile functions is replaced by a carboxylic acid group (24) (Fig. 2). The higher sensitivity of Bis-ANS compared to CCVJ detection is in part due to the relatively higher fluorescence intensity of Bis-ANS (compare also Fig. 3 and 4) and in part due to the experimental settings. The larger Stokes' shift of the emission maximum allows for working with a larger monochromator bandwidth for Bis-ANS. To avoid interference from scattered light during CCVJ detection, a narrower bandwidth of $18 \mathrm{~nm}$ had to be chosen. Moreover, the sensitivity of the PMT detector is lower at $500 \mathrm{~nm}$ than around $490 \mathrm{~nm}$.

A major concern with fluorescent dyes for aggregate characterization is that they might have an effect on the aggregation level of the sample. It has been described in the literature that fluorescent dyes can both promote or inhibit protein aggregation (34-37). However, this is mainly problematic when the dyes are present already during the aggregation process, where they can interact with exposed hydrophobic parts of the protein under stress conditions. In our analytical set-up, the dyes were added after the applied stress prior to analysis and did not induce detectible changes in steady-state fluorescence until at least two hours after addition of the dyes (data not shown). Also, in HP-SEC analysis with dye detection, the formulations have already undergone aggregation prior to the contact with the dye. The comparable UV signals at $280 \mathrm{~nm}$, with respect to total area under the curve and overlapping profiles of the chromatograms obtained for the mobile phases without dye and with Bis-ANS or CCVJ (data not shown), strongly indicate that, for our samples, the dyes added to the eluent did not affect the aggregation profile.

From the UV signal at $280 \mathrm{~nm}$, the aggregate content of the formulations was quantified, as summarized in Table II. Aggregation was more severe after 10 minutes heating at $80^{\circ} \mathrm{C}(78$ to $83 \%$ aggregates $)$ as compared to 10 minutes at $75^{\circ} \mathrm{C}(10$ to $13 \%$ aggregates). A higher aggregate content was observed in the formulations with polysorbate than in the polysorbate-free
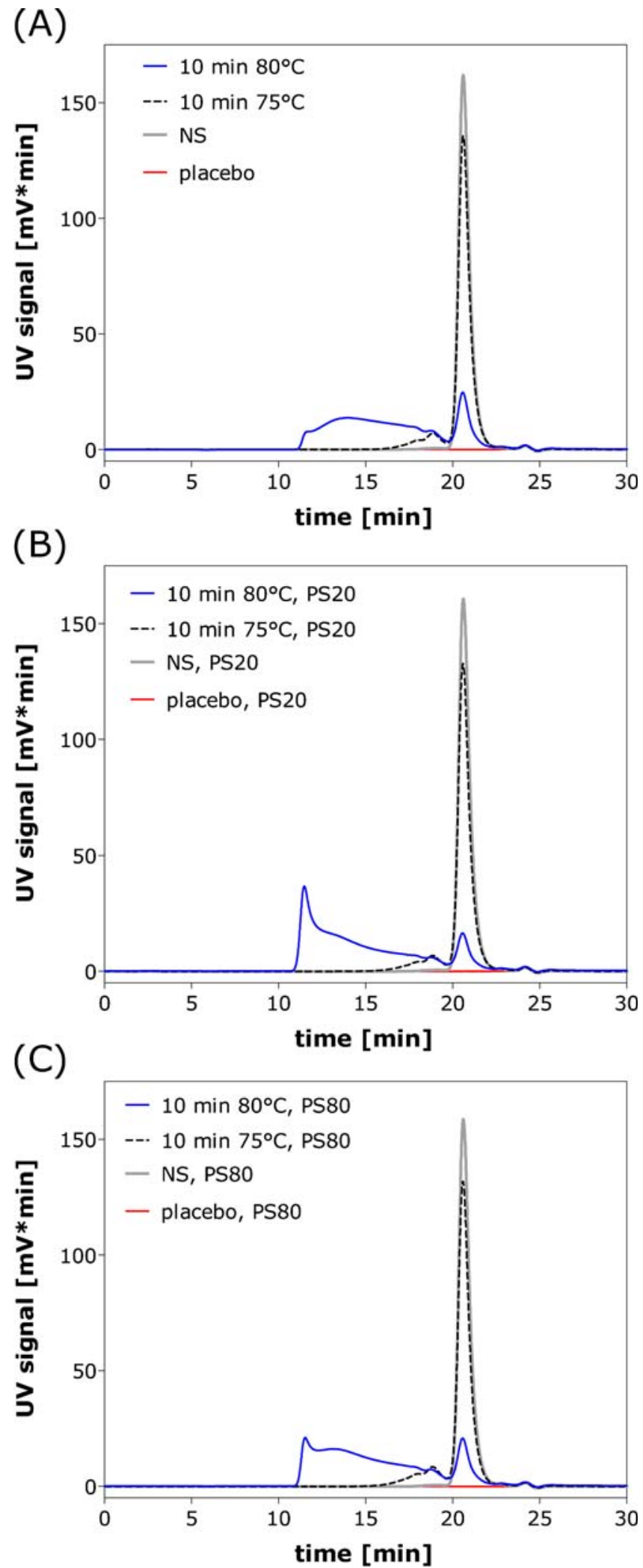

Fig. 5. Representative HP-SEC chromatograms of UV detection at $280 \mathrm{~nm}$ of placebo, non-stressed (NS) IgG and heat-stressed IgG (10 min $75^{\circ} \mathrm{C}$ or $10 \mathrm{~min} 80^{\circ} \mathrm{C}$ ) for polysorbate-free formulations (A), formulations with $0.02 \%$ polysorbate 20 (PS20) (B) and $0.02 \%$ polysorbate 80 (PS80) (C). 
(A)

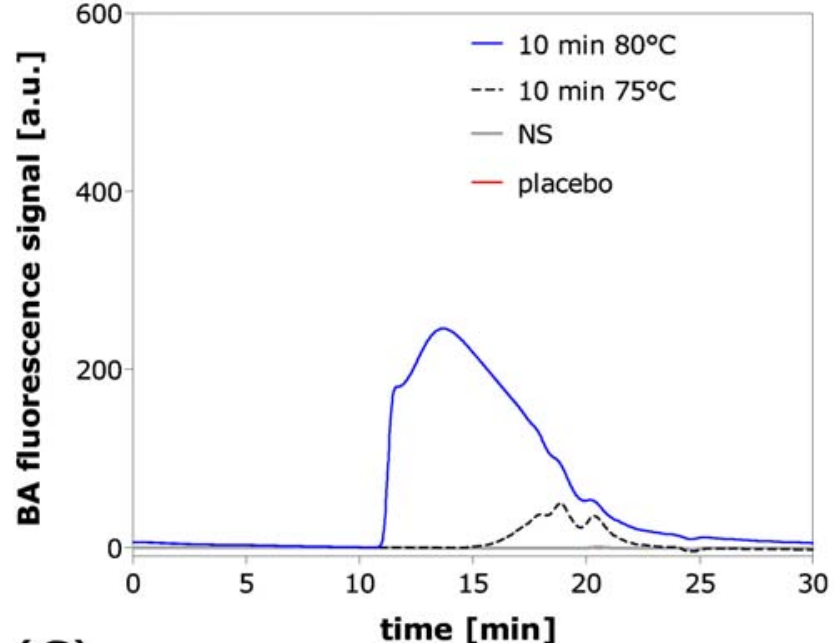

(C)

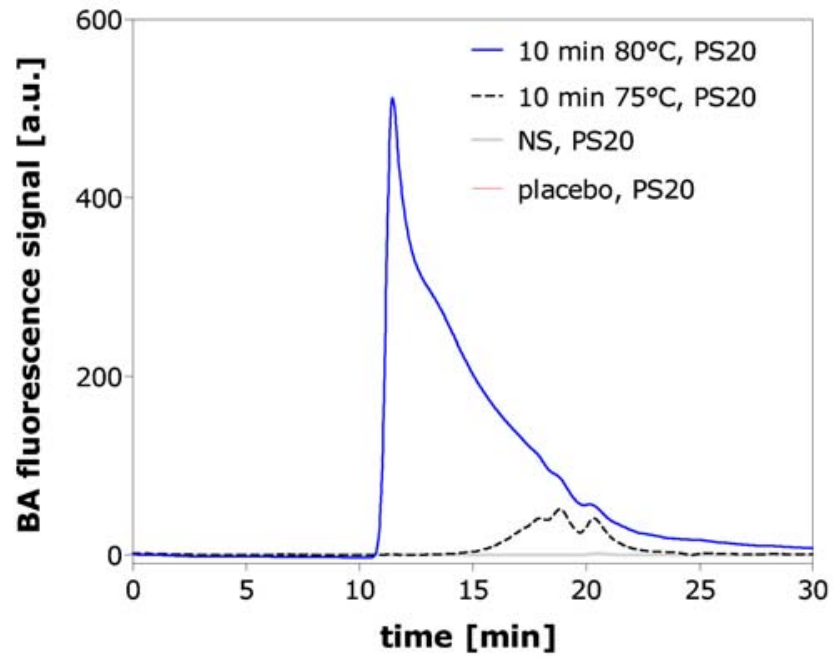

(E)

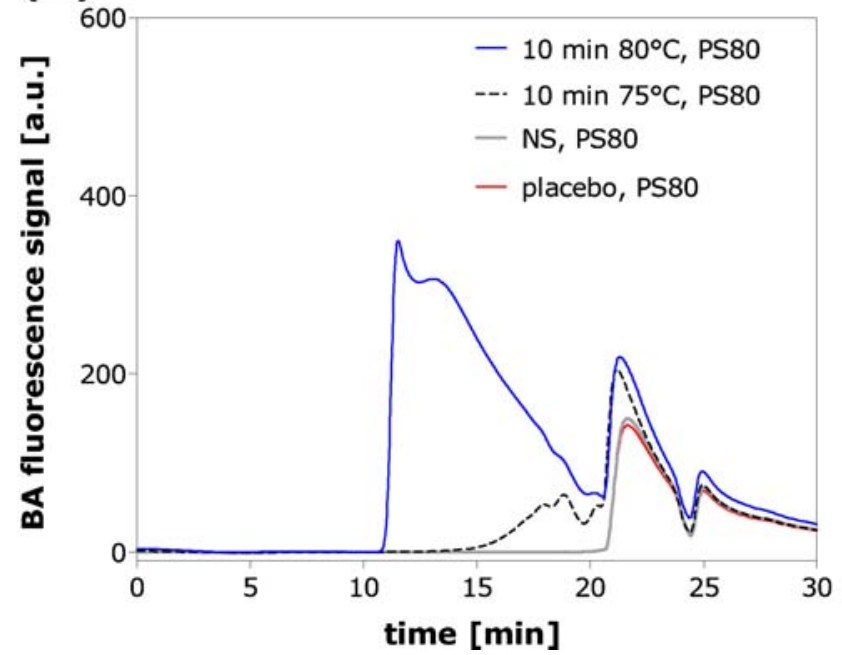

(B)
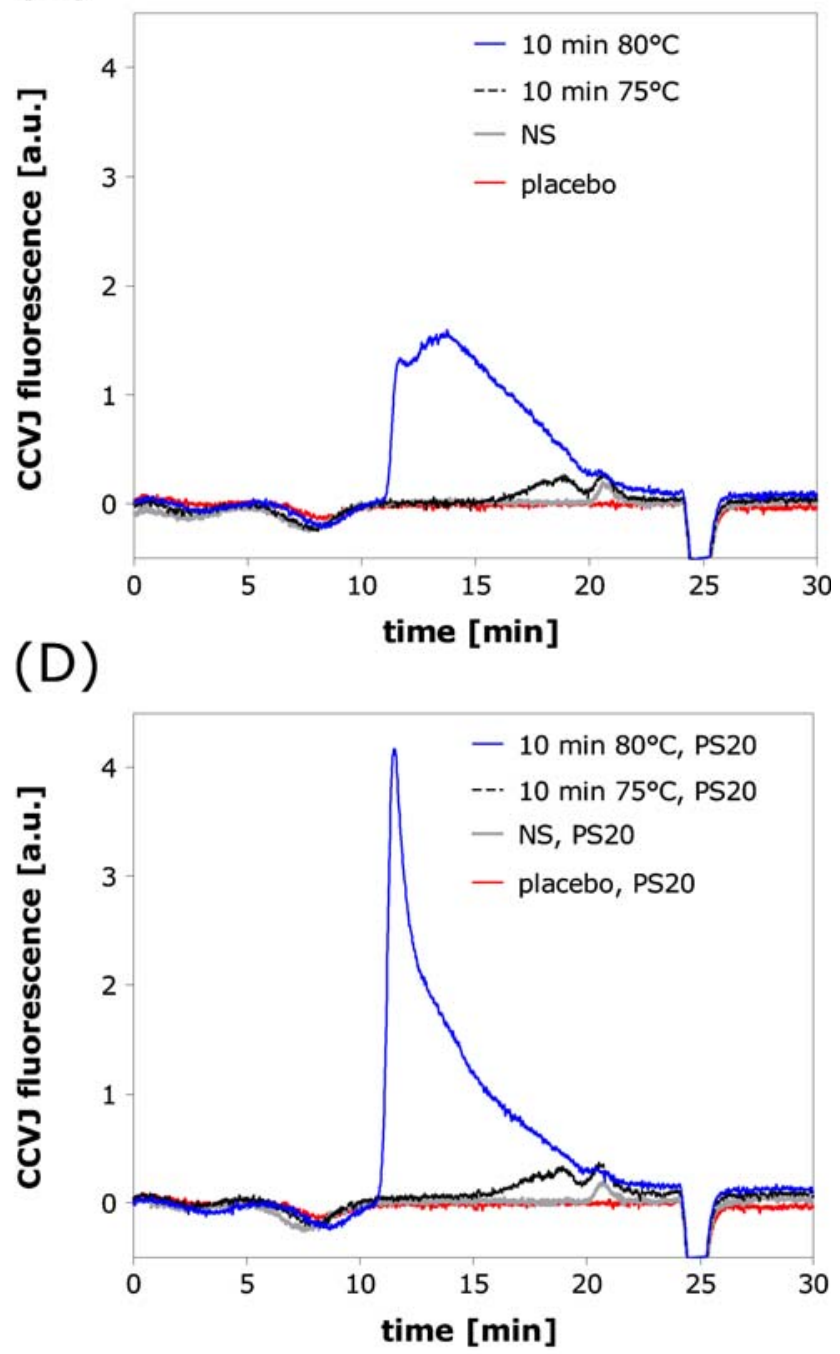

( $F)$

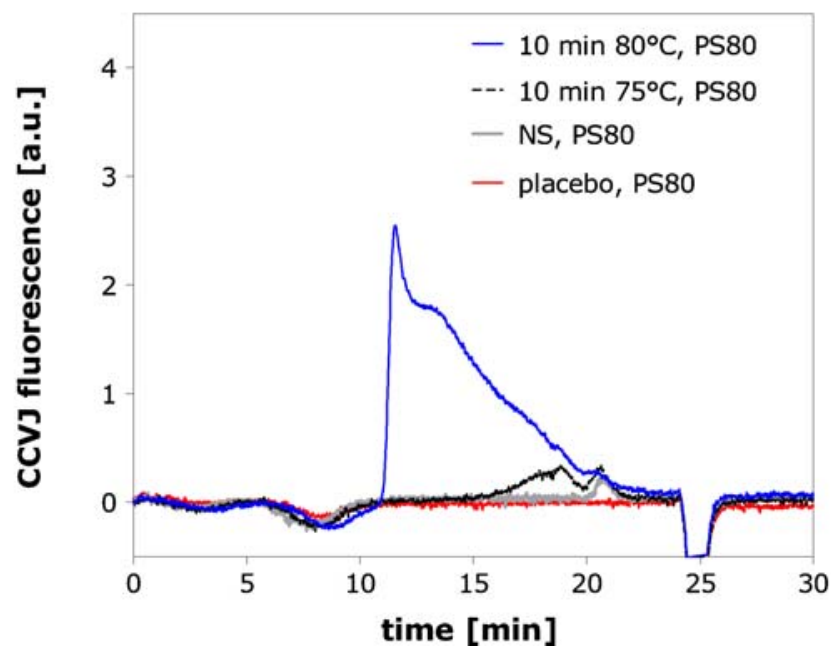

Fig. 6. Representative HP-SEC chromatograms of Bis-ANS detection (A,C,E) and CCVJ detection (B,D,E) of placebo, non-stressed (NS) IgG and heat-stressed $\mathrm{IgG}\left(10 \mathrm{~min} 75^{\circ} \mathrm{C}\right.$ or $\left.10 \mathrm{~min} 80^{\circ} \mathrm{C}\right)$ for polysorbate-free formulations (A,B), formulations with $0.02 \%$ polysorbate 20 (PS20) (C,D) and $0.02 \%$ polysorbate 80 (PS80) (E,F). 
Table II. HP-SEC Results Calculated from UV Absorbance at $280 \mathrm{~nm}$ for the IgG Formulations of $1.0 \mathrm{mg} / \mathrm{ml} \mathrm{IgG}$ in $100 \mathrm{mM}$ Phosphate pH 7.2 Without Polysorbate (PS) or With $0.02 \%$ Polysorbate 20 (PS20) or 80 (PS80) ${ }^{a}$

\begin{tabular}{|c|c|c|c|c|}
\hline Sample & Aggregates [\%] & Monomer [\%] & Fragments [\%] & Relative recovery [\%] \\
\hline NS, $0 \%$ PS & $0.7 \pm 0.1$ & $98.8 \pm 0.1$ & $0.5 \pm 0.1$ & 100.0 \\
\hline $10 \min 75^{\circ} \mathrm{C}, 0 \%$ PS & $10.4 \pm 0.4$ & $89.0 \pm 0.2$ & $0.7 \pm 0.2$ & $95.3 \pm 1.5$ \\
\hline $10 \min 80^{\circ} \mathrm{C}, 0 \% \mathrm{PS}$ & $78.6 \pm 1.1$ & $20.4 \pm 1.0$ & $1.0 \pm 0.1$ & $88.1 \pm 2.4$ \\
\hline NS, $0.02 \%$ PS 20 & $0.7 \pm 0.0$ & $98.8 \pm 0.1$ & $0.5 \pm 0.1$ & 100.0 \\
\hline $10 \min 75^{\circ} \mathrm{C}, 0.02 \% \mathrm{PS} 20$ & $10.7 \pm 0.3$ & $88.7 \pm 0.2$ & $0.7 \pm 0.2$ & $93.2 \pm 0.1$ \\
\hline $10 \min 80^{\circ} \mathrm{C}, 0.02 \%$ PS 20 & $85.1 \pm 1.4$ & $13.8 \pm 1.1$ & $1.1 \pm 0.3$ & $92.5 \pm 3.9$ \\
\hline NS, $0.02 \%$ PS 80 & $0.6 \pm 0.1$ & $98.8 \pm 0.2$ & $0.5 \pm 0.2$ & 100.0 \\
\hline $10 \min 75^{\circ} \mathrm{C}, 0.02 \%$ PS 80 & $13.6 \pm 0.3$ & $85.7 \pm 0.2$ & $0.7 \pm 0.2$ & $94.8 \pm 0.1$ \\
\hline $10 \min 80^{\circ} \mathrm{C}, 0.02 \%$ PS 80 & $82.0 \pm 1.3$ & $16.8 \pm 1.0$ & $1.2 \pm 0.3$ & $93.2 \pm 0.3$ \\
\hline
\end{tabular}

${ }^{a} n=3$, results are presented as average \pm standard deviation

formulations. These tendencies can be found back in the dye detection with qualitatively comparable results for Bis-ANS (Fig. 6A,C,E) and CCVJ (Fig. 6B,D,F). Both dyes exhibited high fluorescence intensities for aggregates eluting between 12 and 19 minutes, with higher intensities for the larger aggregates. Furthermore, a slightly increased intensity for the monomer in heat-stressed preparations was found as compared to the nonstressed monomer, suggesting the presence of conformationally altered monomers. The corresponding placebo formulations exhibited no fluorescence, with the exception of the formulation buffer with $0.02 \%$ polysorbate 80 in Bis-ANS detection. The disturbance of Bis-ANS detection by polysorbate 80 was obvious by an intense fluorescence signal in the fraction eluting between 22 and 25 minutes (Fig. 6E). In the corresponding UV traces at $280 \mathrm{~nm}$, no signal of polysorbate 80 was observed (Fig. 5C). Nevertheless, dye detection with Bis-ANS in HP-SEC was feasible for the formulations without polysorbate and with polysorbate 20 (Fig. 6A,C). CCVJ detection (Fig. 6B,D,F) was not disturbed at all by polysorbate present in the formulations and hence found to be suitable to analyze formulations containing polysorbate 80 .

Generally speaking, online fluorescent dye detection in HP-SEC provides qualitative information on the properties of aggregates and monomer present within a formulation. Although in principle for a defined aggregate (ensemble), the dye fluorescence intensity can be used for quantitative purposes (unpublished results), a straightforward quantification of the aggregate content based on the dye signal is up to now not possible. The reason for this is that the fluorescence intensity not only depends on the amount of aggregates, but also on the properties of the aggregates or other dye-binding species (e.g. monomers, fragments) with respect to polarity (Bis-ANS) or rigidity (CCVJ) of the microenvironment. For quantitative purposes, the UV signal at $280 \mathrm{~nm}$ can be employed. Compared to steady-state fluorescence, online dye detection has the advantage of allowing an assignment of the increased fluorescence to certain protein species.

\section{Case Study: Use of CCVJ to Analyze Aggregation in Enbrel ${ }^{\circledR} 50 \mathrm{mg}$, MabThera ${ }^{\circledR} 100 \mathrm{mg}$ and Humira ${ }^{\circledR} 40 \mathrm{mg}$}

After having shown that molecular rotors are suitable to detect aggregation in polysorbate-containing $\mathrm{IgG}$ formulations, we aimed to use CCVJ for the analysis of commercial protein therapeutics. Possible concerns about using CCVJ for these preparations may be the higher protein concentrations of 10 to $50 \mathrm{mg} / \mathrm{ml}$ and the more complex compositions with respect to excipients. For the study, we selected Enbrel®50 mg, which is polysorbate-free but contains a high concentration of $50 \mathrm{mg} / \mathrm{ml}$ etanercept, and the polysorbate 80-containing monoclonal antibody preparations MabThera ${ }^{\circledR} 100 \mathrm{mg}(10 \mathrm{mg} / \mathrm{ml}$ rituximab and $0.07 \%(\mathrm{w} / \mathrm{v})$ polysorbate 80$)$, as well as Humira ${ }^{\circledR} 40 \mathrm{mg}$ (50 $\mathrm{mg} / \mathrm{ml}$ adalimumab and $0.1 \%(\mathrm{w} / \mathrm{v})$ polysorbate 80$)$. The products were stressed for 10 minutes at different temperatures below the aggregation temperature (determined by UV spectroscopy - data not shown) to obtain aggregate-containing, but optically clear, solutions. HP-SEC confirmed the formation of aggregates by the thermal stressing of the commercial preparation as shown in Fig. 7. The absolute quantity of aggregates obvious from the UV detection at $280 \mathrm{~nm}$ in these high concentrated formulations might be impacted by the dilution effect observed during the HP-SEC analysis (38), but this was not further studied.

In Fig. 8, the analysis of the commercial products with $5 \mu \mathrm{M} \mathrm{CCVJ}$ in steady-state fluorescence spectroscopy is shown. The emission spectrum of CCVJ added to nonstressed Enbrel®50 mg is blue shifted by about $7 \mathrm{~nm}$ and of about 2-fold higher intensity as compared to the placebo with an emission maximum of $500 \mathrm{~nm}$ (Fig. 8A). The blue shift by $7 \mathrm{~nm}$ points at higher hydrophobicity of the non-stressed formulation as compared to the placebo. This may be due to hydrophobic parts present on the native etanercept molecule or on the small amount of aggregates present in the nonstressed preparation (compare Fig. 7A). HP-SEC with CCVJ dye detection revealed that the etanercept monomer is interacting with CCVJ, obvious by the peak eluting at about 18 minutes (Fig. 7B). After stressing Enbrel®50 mg for 10 minutes at $70^{\circ} \mathrm{C}$ a clear, 4-fold increase in fluorescence intensity accompanied by a blue shift of $15 \mathrm{~nm}$ was measured in steady-state fluorescence (Fig. 8A). This can be attributed to the formation of aggregates, which provide a rigid environment for CCVJ (intensity increase) and exhibit a higher hydrophobicity than the non-stressed preparation (blue shift). The interaction of aggregates with CCVJ was also apparent in HP-SEC with CCVJ detection (Fig. 7B).

For the polysorbate 80 -containing products MabThera ${ }^{\circledR}$ $100 \mathrm{mg}$ (Fig. 8B) and Humira®40 mg (Fig. 8C), the emission maxima of the placebos and the non-stressed preparations are 
(A)

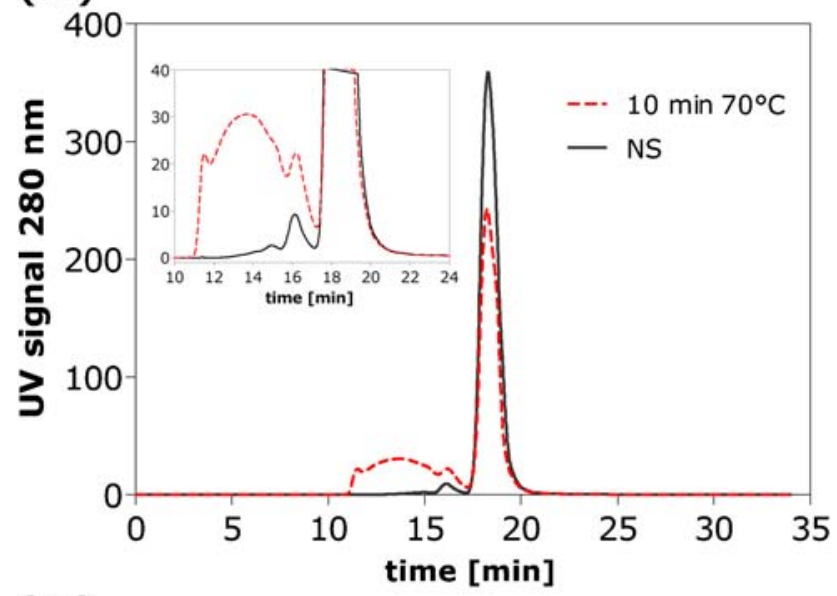

(C)

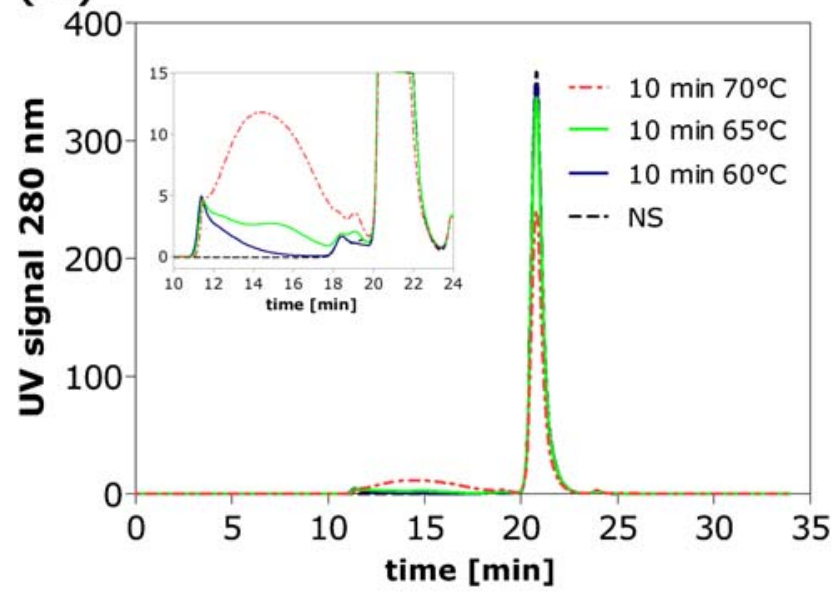

(E)

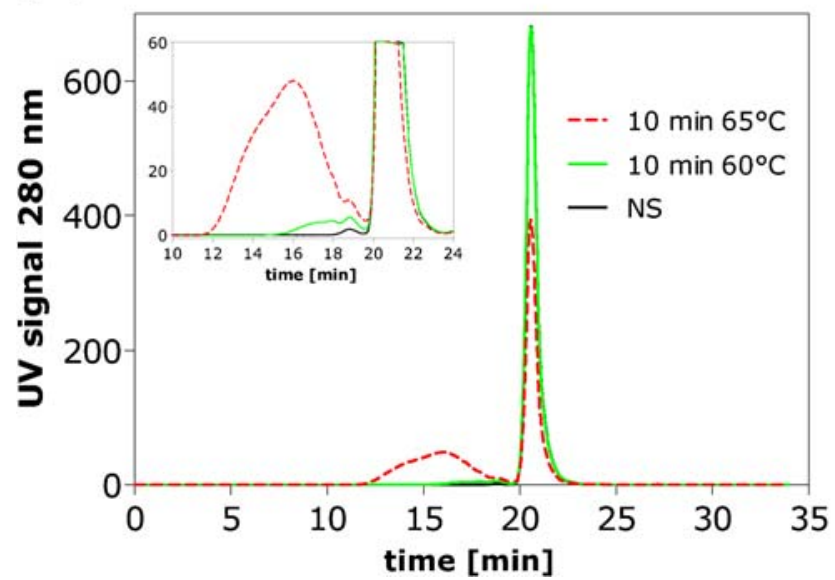

(B)

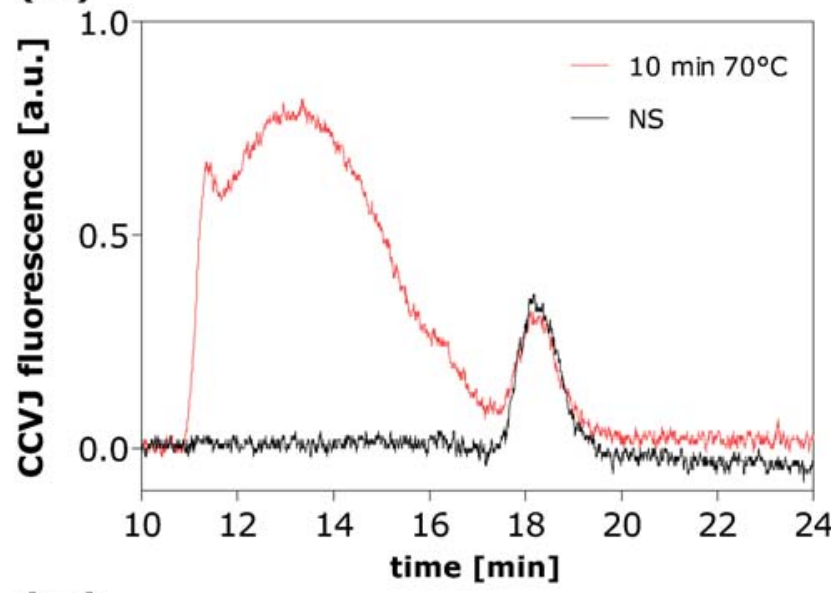

(D)

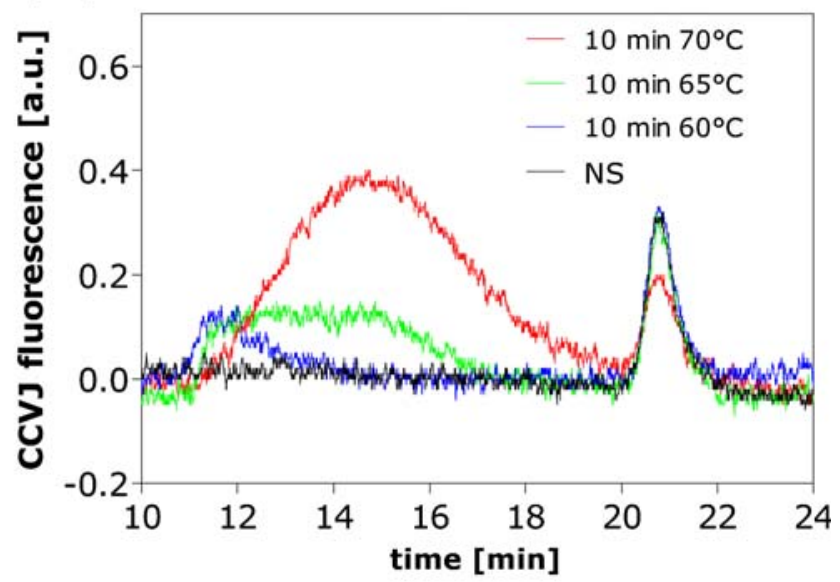

(F)

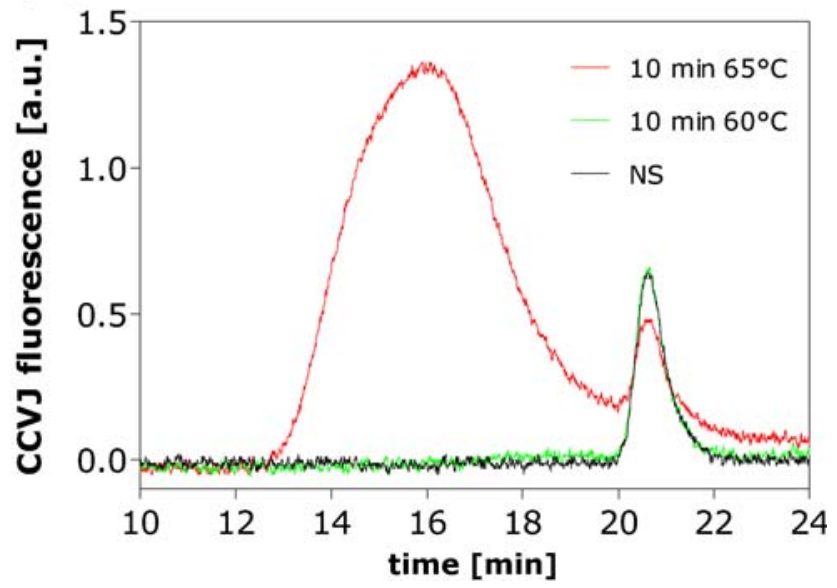

Fig. 7. Representative HP-SEC with UV detection at $280 \mathrm{~nm}(\mathrm{~A}, \mathrm{C}, \mathrm{E})$ and CCVJ dye detection, Exc. $435 \mathrm{~nm}$, Em. $500 \mathrm{~nm}(\mathrm{~B}, \mathrm{D}, \mathrm{F})$ of Enbrel®50 mg (50 mg/ml etanercept) (A,B), MabThera®100 mg (10 mg/ml rituximab) (C,D) and Humira®40 mg (50 mg/ml adalimumab) (E, F). Each commercial preparation was analyzed non-stressed (NS) and after heat stress for 10 minutes at the temperatures indicated in the figure legend. Insets represent a zoom into the chromatograms of the UV detection at $280 \mathrm{~nm}$.

located at $495 \mathrm{~nm}$ for MabThera ${ }^{\circledR} 100 \mathrm{mg}$ and $492 \mathrm{~nm}$ for Humira ${ }^{\circledR} 40 \mathrm{mg}$. The blue shift of the emission as compared to Enbrel ${ }^{\circledR} 50 \mathrm{mg}$ placebo $(500 \mathrm{~nm})$ can be attributed to the more hydrophobic environment because of polysorbate 80 present in these formulations. The fluorescence intensity of the non-stressed preparations was 1.5-fold higher for MabThera ${ }^{\circledR} 100 \mathrm{mg}$ and 2.4-fold higher for Humira ${ }^{\circledR} 40 \mathrm{mg}$ than for the corresponding placebo, whereas the emission maximum was unchanged. Comparable to Enbrel®50 mg, an interaction of CCVJ with the monomer was measured in HP- 
(A)

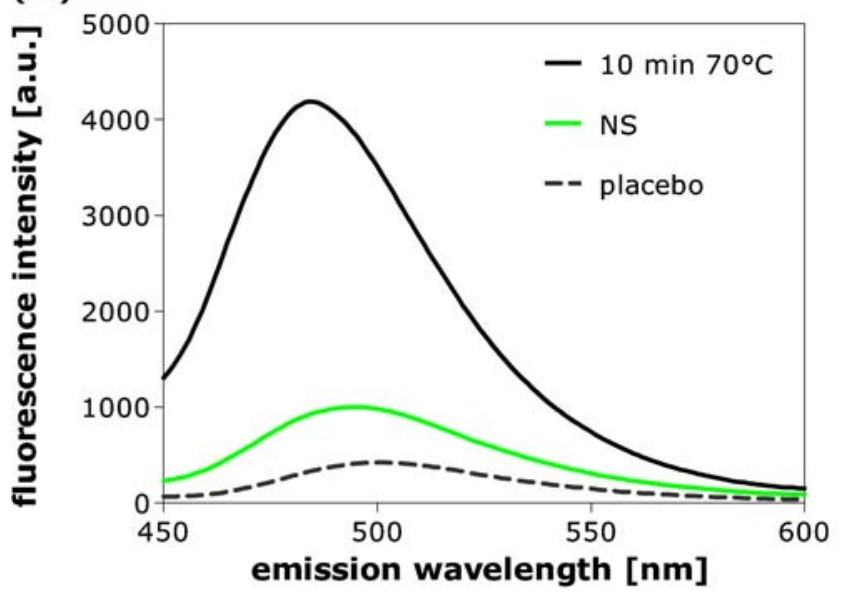

(B)

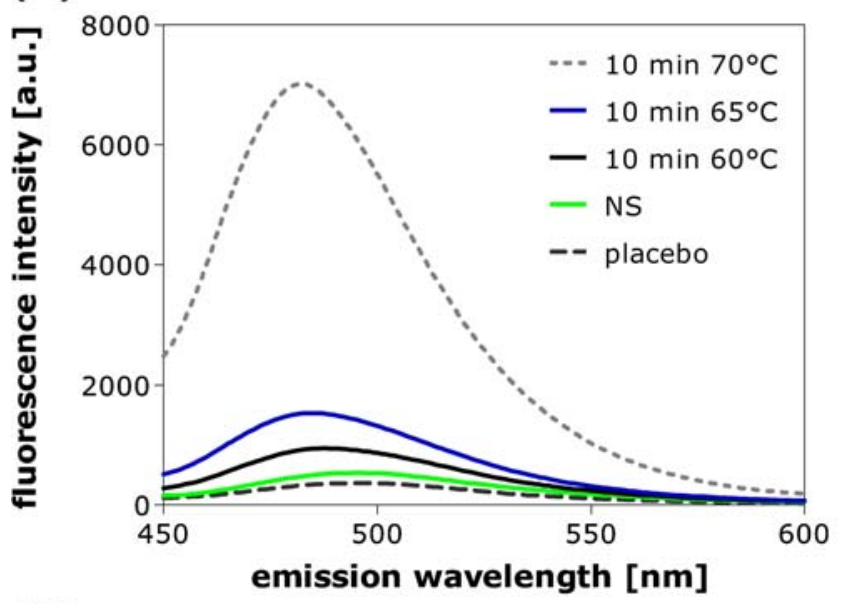

(C)

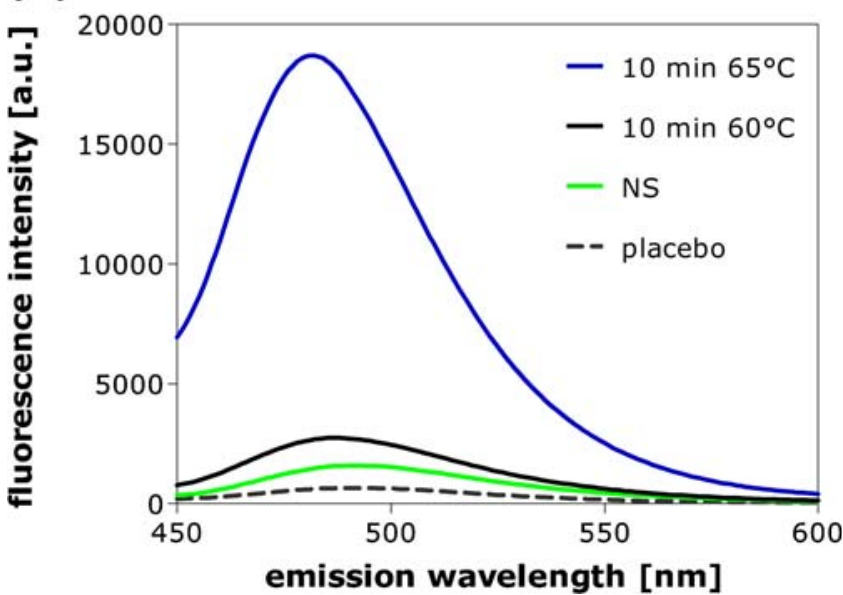

Fig. 8. Steady-state fluorescence spectra (average of $n=3$ ) of $5 \mu \mathrm{M}$ CCVJ added to Enbrel@50 $\mathrm{mg}(50 \mathrm{mg} / \mathrm{ml}$ etanercept) (A), MabThera ${ }^{\circledR} 100 \mathrm{mg}\left(10 \mathrm{mg} / \mathrm{ml}\right.$ rituximab) (B) and Humira ${ }^{\circledR} 40 \mathrm{mg}$ (50 $\mathrm{mg} / \mathrm{ml}$ adalimumab) (C). For each product, a protein-free placebo, as well as the commercial preparation non-stressed (NS) and heat stressed for 10 minutes at the temperatures indicated in the figure legend were analyzed. The relative standard deviations of the maximum intensity were $<1 \%$ for placebo and $<5 \%$ for the protein formulations, with exception of MabThera ${ }^{\circledR} 100 \mathrm{mg}$ stressed for 10 minutes at $70^{\circ} \mathrm{C}(12 \%)$.
SEC with CCVJ detection for both MabThera ${ }^{\circledR} 100 \mathrm{mg}$ (Fig. 7D) and Humira®40 mg (Fig. 7F).

An increase in CCVJ fluorescence and a blue shift was monitored in steady-state fluorescence spectroscopy (Fig. 8B, C) for the heat-stressed products of MabThera ${ }^{\circledR} 100 \mathrm{mg}$ and Humira ${ }^{\circledR 40} \mathrm{mg}$, which is in agreement with the increase in aggregation measured by HP-SEC with UV (Fig. 7C,E) and CCVJ detection (Fig. 7D,F). Overall, it is possible to detect changes in the highly concentrated commercial preparation by the molecular rotor CCVJ, even at relatively high protein and polysorbate 80 concentrations.

\section{CONCLUSIONS}

We have proven that the fluorescent molecular rotors DCVJ and CCVJ are valuable dyes to detect changes in polysorbate-containing thermally-stressed, aggregated IgG formulations in steady-state fluorescence spectroscopy. As their fluorescence properties are hardly affected by polysorbate at concentrations typically used in pharmaceutical protein formulations, these dyes are superior over the polarity-sensitive dyes (Bis-)ANS and Nile Red for the characterization of polysorbate-containing protein formulations. Moreover, CCVJ can be used within the mobile phase of the HP-SEC for the analysis of polysorbate-containing samples using online fluorescence detection. The suitability of the molecular rotor CCVJ was also shown for the analysis of highly-concentrated, polysorbate-containing commercial formulations of therapeutic proteins. Our findings open up new possible applications of fluorescent molecular rotors, specifically DCVJ and CCVJ, in (high-throughput) formulation screening and stability testing of protein formulations containing polysorbate as stabilizer.

\section{ACKNOWLEDGMENTS}

This research is supported by the Dutch Technology Foundation STW, applied science division of NWO and the Technology Program of the Ministry of Economic Affairs.

Open Access This article is distributed under the terms of the Creative Commons Attribution Noncommercial License which permits any noncommercial use, distribution, and reproduction in any medium, provided the original author(s) and source are credited.

\section{REFERENCES}

1. Norde W. Adsorption of proteins at solid-liquid interfaces. Cells Mater. 1995;5:97-112.

2. Kreilgaard L, Jones LS, Randolph TW, Frokjaer S, Flink JM, Manning MC, et al. Effect of Tween 20 on freeze-thawing- and agitation-induced aggregation of recombinant, human factor XIII. J Pharm Sci. 1998;87:1597-603.

3. Sarciaux JM, Mansour S, Hageman MJ, Nail SL. Effects of buffer composition and processing conditions on aggregation of bovine IgG during freeze-drying. J Pharm Sci. 1999;88:1354-61.

4. Kiese S, Papppenberger A, Friess W, Mahler HC. Shaken, not stirred: mechanical stress testing of an IgG1 antibody. J Pharm Sci. 2008;97:4347-66.

5. Thirumangalathu R, Krishnan S, Ricci MS, Brems DN, Randolph TW, Carpenter JF. Silicone oil- and agitation-induced aggregation 
of a monoclonal antibody in aqueous solution. J Pharm Sci. 2009;98:3167-81.

6. Jones LS, Randolph TW, Kohnert U, Papadimitriou A, Winter G, Hagmann ML, et al. The effects of tween 20 and sucrose on the stability of anti-L-selectin during lyophilization and reconstitution. J Pharm Sci. 2001;90:1466-77.

7. Wang W, Wang YJ, Wang DQ. Dual effects of Tween 80 on protein stability. Int J Pharm. 2008:347:31-8.

8. Kerwin BA. Polysorbates 20 and 80 used in the formulation of protein biotherapeutics: structure and degradation pathways. J Pharm Sci. 2008;97:2924-35.

9. Chames P, Van Regenmortel M, Weiss E, Baty D. Therapeutic antibodies: successes, limitations and hopes for the future. Br J Pharmacol. 2009;157:220-33.

10. Daugherty AL, Mrsny RJ. Formulation and delivery issues for monoclonal antibody therapeutics. Adv Drug Deliv Rev. 2006;58:686-706.

11. Centocor/Lilly. Repro, full prescribing information. (11/2005).

12. Genentech. Raptiva, full prescribing information. (03/2009).

13. Hawe A, Sutter M, Jiskoot W. Extrinsic fluorescent dyes as tools for protein characterization. Pharm Res. 2008;25:1487-99.

14. Capelle MA, Gurny R, Arvinte T. A high throughput protein formulation platform: case study of salmon calcitonin. Pharm Res. 2009;26:118-28.

15. Hawe A, Kasper JC, Friess W, Jiskoot W. Structural properties of monoclonal antibody aggregates induced by freeze-thawing and thermal stress. Eur J Pharm Sci. 2009;38:79-87.

16. Lindgren $M$, Sorgjerd $K$, Hammarstrom P. Detection and characterization of aggregates, prefibrillar amyloidogenic oligomers, and protofibrils using fluorescence spectroscopy. Biophys J. 2005;88:4200-12.

17. Hawe A, Friess W, Sutter M, Jiskoot W. Online fluorescent dye detection method for the characterization of immunoglobulin $G$ aggregation by size exclusion chromatography and asymmetrical flow field flow fractionation. Anal Biochem. 2008;378:115-22.

18. Lee K, Shin SC, Oh I. Fluorescence spectroscopy studies on micellization of poloxamer 407 solution. Arch Pharm Res. 2003;26:653-8

19. Mohr A, Talbiersky P, Korth HG, Sustmann R, Boese R, Blaser $\mathrm{D}$, et al. A new pyrene-based fluorescent probe for the determination of critical micelle concentrations. J Phys Chem B. 2007;111:12985-92.

20. Zhang X, Jackson JK, Burt HM. Determination of surfactant critical micelle concentration by a novel fluorescence depolarization technique. J Biochem Biophys Methods. 1996;31:145-50.

21. Brito RMM, Vaz WLC. Determination of the Critical Micelle Concentration of Surfactants Using the Fluorescent-Probe NPhenyl-1-Naphthylamine. Anal Biochem. 1986;152:250-5.
22. Haidekker MA, Brady TP, Lichlyter D, Theodorakis EA. Effects of solvent polarity and solvent viscosity on the fluorescent properties of molecular rotors and related probes. Bioorg Chem. 2005:33:415-25.

23. Kung CE, Reed JK. Fluorescent molecular rotors - a new class of probes for tubulin structure and assembly. Biochemistry. 1989; 28:6678-86.

24. Haidekker MA, Ling TT, Anglo M, Stevens HY, Frangos JA, Theodorakis EA. New fluorescent probes for the measurement of cell membrane viscosity. Chem Biol. 2001;8:123-31.

25. Akers W, Haidekker MA. A molecular rotor as viscosity sensor in aqueous colloid solutions. J Biomech Eng-Trans ASME. 2004; 126:340-5.

26. Amgen/Wyeth. Enbrel, full prescribing information. (09/2009).

27. Abbott-Laboratories. Humira, full prescribing information. (03/ 2009).

28. EMEA. MabThera-Product Information. edition 27.09.2009. London, UK: European Medicines agencies (EMEA) (2000).

29. Yu XC, Margolin W. Inhibition of assembly of bacterial cell division protein FtsZ by the hydrophobic dye 5, 5 '-bis-(8-anilino1-naphthalenesulfonate). J Biol Chem. 1998;273:10216-22.

30. Castro GR, Larson BK, Panilaitis B, Kaplan DL. Emulsan quantitation by Nile red quenching fluorescence assay. Appl Microbiol Biotechnol. 2005;67:767-70.

31. Chang TL, Cheung HC. A model for molecules with twisted intramolecular charge-transfer characteristics - solvent polarity effect on the nonradiative rates of dyes in a series of water ethanol mixed-solvents. Chem Phys Lett. 1990;173: 343-8.

32. Das K, Sarkar N, Nath D, Bhattacharyya K. Nonradiative pathways of anilino-naphthalene sulfonates - twisted intramolecular charge-transfer versus intersystem crossing. Spectrochim Acta Part A: Mol Biomol Spectrosc. 1992;48: 1701-5.

33. Kurosawa S, Tawara E, Kamo N, Kobatake Y. Oscillating frequency of piezoelectric quartz crystal in solutions. Anal Chim Acta. 1990;230:41-9.

34. Acharya P, Rao NM. Stability studies on a lipase from Bacillus subtilis in guanidinium chloride. J Protein Chem. 2003;22:51-60.

35. Fu X, Zhang X, Chang Z. 4, 4'-Dianilino-1, 1'-binaphthyl-5, 5'sulfonate, a novel molecule having chaperone-like activity. Biochem Biophys Res Commun. 2005;329:1087-93.

36. Kundu B, Guptasarma P. Hydrophobic dye inhibits aggregation of molten carbonic anhydrase during thermal unfolding and refolding. Proteins. 1999;37:321-4.

37. Sereikaite J, Bumelis VA. Congo red interaction with alphaproteins. Acta Biochim Pol. 2006;53:87-92.

38. Philo JS. Is any measurement method optimal for all aggregate sizes and types? AAPS J. 2006;8:E564-571. 